\title{
Connections among soil, ground, and surface water chemistries characterize nitrogen loss from an agricultural landscape in the upper Missouri River basin
}

\author{
Authors: W. Adam Sigler, Stephanie A. Ewing, Clain \\ A. Jones, Robert A. Payn, E. N. Jack Brookshire, \\ Jane K. Klassen, Douglas Jackson-Smith, and Gary S. \\ Weissmann
}

NOTICE: this is the author's version of a work that was accepted for publication in Journal of Hydrology. Changes resulting from the publishing process, such as peer review, editing, corrections, structural formatting, and other quality control mechanisms may not be reflected in this document. Changes may have been made to this work since it was submitted for publication. A definitive version was subsequently published in Journal of Hydrology, VOL\# 556, (January 2018) DOI\# 10.1016/j.jhydrol.2017.10.018.

Sigler, W. Adam, Stephanie A. Ewing, Clain A. Jones, Robert A. Payn, E.N. Jack Brookshire, Jane K. Klassen, Douglas Jackson-Smith, and Gary S. Weissmann. "Connections among soil, ground, and surface water chemistries characterize nitrogen loss from an agricultural landscape in the upper Missouri River basin." Journal of Hydrology 556 (January 2018): 247-261. DOI: 10.1016/j.jhydrol.2017.10.018. 


\title{
Connections among soil, ground, and surface water chemistries characterize nitrogen loss from an agricultural landscape in the upper Missouri River Basin
}

\author{
W. Adam Sigler ${ }^{\mathrm{a}, \mathrm{b}, *}$, Stephanie A. Ewing ${ }^{\mathrm{a}}$, Clain A. Jones ${ }^{\mathrm{a}, \mathrm{b}}$, Robert A. Payn ${ }^{\mathrm{a}, \mathrm{c}}$, E.N. Jack Brookshire ${ }^{\mathrm{a}}$, \\ Jane K. Klassen ${ }^{\mathrm{a}}$, Douglas Jackson-Smith ${ }^{\mathrm{d}}$, Gary S. Weissmann ${ }^{\mathrm{e}}$ \\ ${ }^{a}$ Land Resources \& Environmental Sciences, Montana State University, Bozeman, MT, United States \\ ${ }^{\mathrm{b}}$ Montana State University Extension, Bozeman, MT, United States \\ ${ }^{\mathrm{c}}$ Montana Institute on Ecosystems, Montana University System, MT, United States \\ ${ }^{\mathrm{d}}$ School of Environment and Natural Resources, The Ohio State University, Wooster, OH, United States \\ ${ }^{\mathrm{e}}$ Earth $\mathcal{E}$ Planetary Sciences, University of New Mexico, Albuquerque, NM, United States
}

\begin{abstract}
A B S T R A C T
Elevated nitrate in shallow aquifers is common in agricultural areas and remediation requires an understanding of nitrogen $(\mathrm{N})$ leaching at a variety of spatial scales. Characterization of the drivers of nitrate leaching at the mesoscale level $\left(10^{2}-10^{3} \mathrm{~km}^{2}\right)$ is needed to bridge from field-scale observations to the landscape-scale context, allowing informed water resource management decisions. Here we explore patterns in nitrate leaching rates across a depositional landform in the northern Great Plains within the Upper Missouri Basin, where the predominant land use is non-irrigated small grain production, and nitrate- $\mathrm{N}$ concentrations above $10 \mathrm{mg} \mathrm{L}^{-1}$ are common. The shallow Moccasin terrace $\left(260 \mathrm{~km}^{2}\right)$ aquifer is bounded in vertical extent by underlying shale and is isolated from mountain front stream recharge, such that aquifer recharge is dominated by infiltration of precipitation through agricultural soils. This configuration presents a simple landform-scale water balance that we leveraged to estimate leaching rates using groundwater nitrate concentrations and surface water discharge, and quantify uncertainty using a Monte Carlo approach based on spatial variation in observations of groundwater nitrate concentrations. A participatory research approach allowed local farmer knowledge of the landscape to be incorporated into the study design, improved selection of and access to sample sites, and enhanced prospects for addressing nitrate leaching through collaborative understanding of system hydrology. Mean landform-scale nitrate-N leaching rates were 11 and $18 \mathrm{~kg} \mathrm{ha}^{-1} \mathrm{yr}^{-1}$ during the 2012-2014 study for the two largest catchments draining the terrace. Over a standard three-year crop rotation, these leaching rates represent $19-31 \%$ of typical fertilizer $\mathrm{N}$ application rates; however, leaching losses are likely derived not only from fertilizer but also from soil organic $\mathrm{N}$ mineralization, and are apparently higher during the post-fallow phase of the crop rotation. Groundwater apparent age is relatively young ( $0-5 \mathrm{yr}$ ) based on tritium-helium analysis, but whole-aquifer turnover time calculations are an order of magnitude longer (20-23 yr), suggesting changes in groundwater may lag behind changes in land management by years to decades.
\end{abstract}

\section{Introduction}

An estimated sixty percent of $\mathrm{N}$ inputs for production of goods and services in the United States (US) is lost due to inefficiency, where one third of these losses are routed to ground and surface water (Houlton et al., 2013). Nitrogen losses associated with low $\mathrm{N}$ use efficiency have thus polluted drinking water sources and compromised aquatic ecosystem integrity across the globe, and $\mathrm{N}$ pollution is expected to increase in regions with increasing population or development (Spalding and Exner, 1993; Vitousek, 1994; Smith, 2003; Diaz and Rosenberg, 2008). Total N concentration in streams draining areas of agricultural land use are commonly six times greater than background levels (Dubrovsky et al., 2010). Such effects are particularly evident in the Mississippi 
Atchafalaya River Basin (MARB) where N flux to the Gulf of Mexico increased threefold in the second half of the 20th century (Goolsby and Battaglin, 2001). These $\mathrm{N}$ fluxes are more than 60\% nitrate- $\mathrm{N}$, which is thought to be transported to ground and surface water primarily from microbial mineralization of soil organic N (SON) and fertilizer leached from agricultural soils (Goolsby et al., 1999). In this study, we examine causes of high nitrate ( $\left.\mathrm{NO}_{3}^{-}\right)$levels in groundwater and streams within an extensively cultivated 260 $\mathrm{km}^{2}$ (26,000 ha) landform in the Upper Missouri Basin headwaters of the MARB. We link observations of water quality in cultivated soil, ground, and surface waters at this intermediate scale (mesoscale: $10^{2}-10^{3} \mathrm{~km}^{2}$ ) to estimate nitrate leaching rates, characterize the drivers of $\mathrm{N}$ loss, and suggest implications for water resource quality management in the region.

Despite the general understanding that mineralized SON and fertilizer play an important role in generating the large nitrate loads to the MARB (Goolsby et al., 1999), there remains considerable uncertainty about the subsurface dynamics that control these fluxes. Understanding subsurface $\mathrm{N}$ processing and transport to groundwater is particularly important for mitigating surface water $\mathrm{N}$ loads in catchments with a high baseflow index, where the majority of stream flow generation is sourced from groundwater (Dubrovsky et al., 2010; Tesoriero et al., 2013). In addition, groundwater nitrate levels are above the $10 \mathrm{mg} \mathrm{L}^{-1}$ drinking water standard (Ward et al., 2005) in 20\% of shallow domestic wells in US agricultural areas (Dubrovsky et al., 2010). The number of wells exceeding the standard increased by $\sim 5 \%$ between $\sim 1990$ and $\sim 2000$ (Dubrovsky et al., 2010) and average nitrate-N in agricultural area wells has increased $1-2 \mathrm{mg} \mathrm{L}^{-1}$ per decade since the 1940s (Puckett et al., 2011). These increases have led to mounting health and economic costs borne by private well owners and municipal water suppliers (Ward et al., 2005; Bauder and Smith, 2011; Keeler and Polasky, 2014).

Nitrogen loss to ground and surface water can be characterized at a range of spatial scales, each integrating different sets of transport and loss mechanisms. In-stream $\mathrm{N}$ yields of $<1$ to $26 \mathrm{~kg} \mathrm{~N}$ ha $-1 \mathrm{yr}^{-1}$ estimated for large basins $\left(>\sim 10^{3} \mathrm{~km}^{2}\right.$ or $\left.>\sim 10^{5} \mathrm{ha}\right)$ within the MARB represent an integration of all $\mathrm{N}$ sources and pathways, as well as processing and loss within riparian corridors during transport (Goolsby et al., 1999). These values are highly relevant for prioritization of efforts to manage eutrophication in the Gulf of Mexico, but have limited utility for understanding the undoubtedly diverse mechanisms of $\mathrm{N}$ dynamics across the central North American continent. In contrast, specific soil leaching dynamics are more readily isolated at the point-scale $\left(<1 \mathrm{~m}^{2}\right)$. While leaching rates measured at this scale can range over two orders of magnitude (Beaudoin et al., 2005), aggregation of point observations at the field-scale $\left(1-10^{2} \mathrm{ha}\right)$ has effectively allowed estimates of leaching rates ( $<5$ to $69 \mathrm{~kg} \mathrm{~N} \mathrm{ha}^{-1} \mathrm{yr}^{-1}$ ) that can be tied to drivers like crop type, soil character, and inter-annual variation in conditions (Beaudoin et al., 2005; Campbell et al., 2006; John et al., 2017). Thus, nitrate leaching rates and drivers identified at pointand field-scales can directly inform farm $\mathrm{N}$ management decisions. At the same time, there is no assurance that those rates and drivers are representative of landscape-scale ( $>10^{4} \mathrm{ha}$ ) variability. Conversely, nitrate observations that aggregate landscape-scale processes can identify water quality impairment and general sources, but the heterogeneity of pathways from sources along with $\mathrm{N}$ losses in transit impede efforts to quantify leaching rates and isolate specific drivers (Kunstmann and Kastens, 2006; Hansen et al., 2007; Dubrovsky et al., 2010; Pizzol et al., 2015). The question remains: How do $\mathrm{N}$ dynamics operating in soil at the point-scale $\left(<1 \mathrm{~m}^{2}\right)$ manifest in patterns of $\mathrm{N}$ fluxes observed at the spatially aggregated scale of entire agricultural catchments?

To address this central question, we evaluated mesoscale aquifer systems defined by local geomorphic and hydrogeologic con- text (Weissmann et al., 1999; Hancock and Anderson, 2002; Montgomery, 2004). Our study area lies within a central Montana watershed with elevated and increasing nitrate concentrations in groundwater. In particular, we sought a simplified hydrologic system, where stream flow generation is dominated by groundwater sources (i.e. minimal infiltration excess overland flow and interflow) and groundwater recharge is dominated by infiltration from overlying soils (i.e. an aquifer with no groundwater inputs from surrounding areas). We selected a $260-\mathrm{km}^{2}$ strath terrace hosting a shallow unconfined aquifer with elevated nitrate, almost exclusively managed for non-irrigated cereal production (Miller, 2013). The terrace represents a process domain (Montgomery, 1999) with well-defined boundaries and a shallow, oxygenated, high-conductivity aquifer. The system allows landscape-scale estimates of leaching based on time series observations of nitrate concentrations in groundwater wells and surface water discharge (Q). Our first hypothesis was that ground and surface water chemistry is primarily controlled by the aggregate character of terrace soils draining to the sampling location, because groundwater recharge is derived exclusively from local soils. As a result, we expected chemistry of ground and surface water to reflect chemistry of soils within a catchment. We hypothesized that the physical character of this landform promotes oxygenated conditions and short residence times in the shallow aquifer, resulting in minimal denitrification in groundwater. We further hypothesized that high $\mathrm{N}$ loading and biotic activity in the riparian corridors likely result in substantial denitrification. Thus, we expected groundwater nitrate concentrations would be similar to soil water concentrations measured in lysimeters during leaching periods, but that surface water concentrations would be lower than groundwater concentrations due to losses in the riparian corridors. Our approach to addressing these hypotheses and the overarching research question was to characterize soil connectivity to ground and surface water sampling locations based on chemical tracers, estimate the landscape-scale nitrate budget for the terrace aquifer, and constrain the residence time of water in the aquifer to understand the potential time scale of nitrate concentration response to management changes. This research was framed using a community-based participatory approach described in detail in a companion paper (Jackson-Smith et al., in review) and in the supplemental materials. Our approach engaged agricultural producers in understanding sources of nitrate in ground and surface water and testing farm management practices for effectiveness at reducing nitrate leaching (John et al., 2017).

\section{Methods}

\subsection{Study area}

The study area is located within the Judith River Watershed (HUC 10040103), which drains $7200 \mathrm{~km}^{2}$ of central MT into the Missouri River. The Montana State University (MSU) Central Agricultural Research Center (CARC) near the center of the watershed reports an average annual precipitation of $389 \mathrm{~mm}$ for the period of record from 1909 to 2014 (WRCC Gage \# 245761). Heaviest precipitation typically occurs in May and June with the two-month mean representing about $40 \%$ of annual precipitation. The study area is within the northern Great Plains (NGP) agroecoregion (Padbury et al., 2002), which roughly corresponds to the westcentral semi-arid prairies Level II ecoregion (Fig. 1a; CEC, 2006). Annual crops in the NGP have traditionally been dominated by small grain (winter wheat, spring wheat, and barley) with wholeyear summer fallow included in the crop rotation. Pulse crops (e.g. lentil, field pea) have replaced fallow in parts of the NGP 


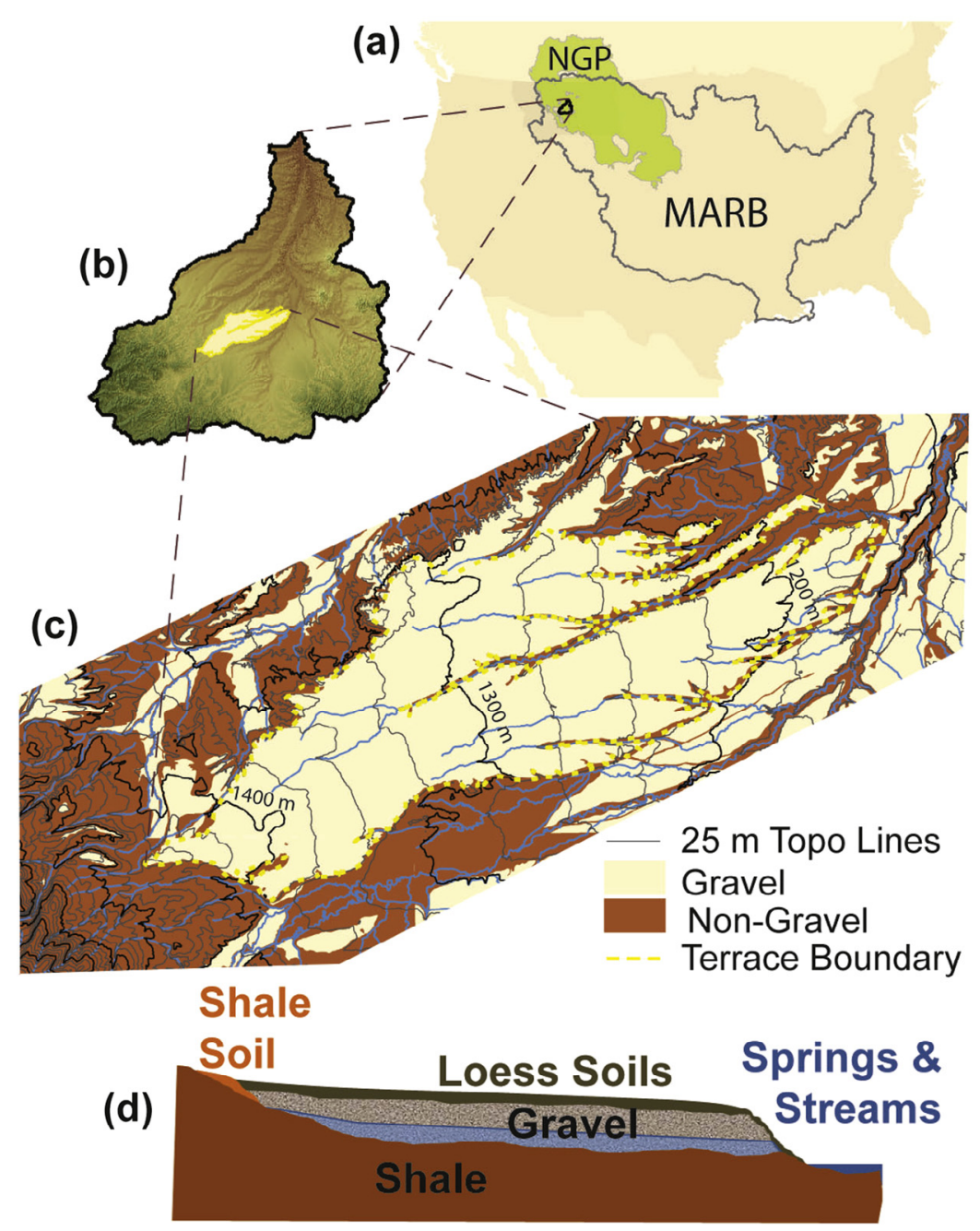

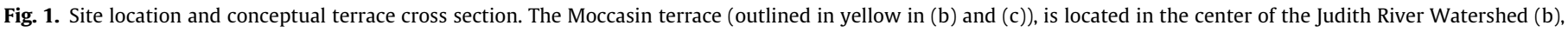

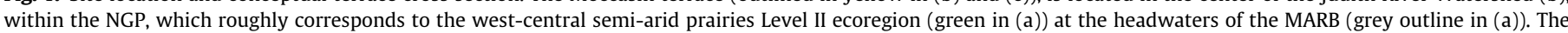

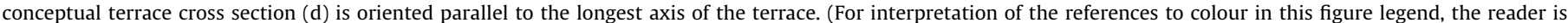
referred to the web version of this article.)

(Long et al., 2014), but small grain-fallow systems continue to dominate the study area (USDA, 2014).

Cropland in fallow represents an elevated risk of nitrate leaching to groundwater and has been implicated as a likely cause of elevated groundwater nitrate in this region (Custer, 1976; Bauder et al., 1993; Schmidt and Mulder, 2010). Groundwater nitrate contamination in the Judith River Watershed is most evident in shallow alluvial aquifers within gravel terraces and alluvial fans at lower-elevation and lower-relief areas of the watershed (Schmidt and Mulder, 2010; Fig. 1d). Terraces and fans are underlain by a relatively impermeable shale unit approximately $300 \mathrm{~m}$ thick (Vuke et al. 2002; Fig. 1d; supplemental materials), the top of which defines the lower boundary of the shallow gravel aquifers.

The Moccasin terrace (Fig. 1) provides a simplified case study of a gravel bench aquifer that receives recharge only from precipitation and infiltration on the terrace surface. In this system, mountain front streams are incised below the shale surface (Fig. 1c), preventing recharge from mountain front surface runoff (Covino and McGlynn, 2007) or groundwater flow (Carling et al., 2012), that occurs in other systems. Highly conductive gravel substrate and a relatively shallow aquifer thickness in the Moccasin Terrace result in relatively young groundwater, with estimated mean residence times on the order of one to ten years (Miller, 2013). Vulnerability of the aquifer to contamination is a function of its proximity to the surface (1-10 m depth to water table) and overlying soils with high infiltration capacity and low field capacity. The majority of the terrace surface (89\%) is covered with clay loam soils with relatively thin zones of fine-textured horizons (ca. $30-100 \mathrm{~cm}$ ) over horizons dominated by alluvial gravels and cobbles (ca. 1-20 cm diameter). Where the transition to these alluvial gravels is shallow, clay accumulation is limited and soils are classified as Judith series. Where the transition is deeper, clay content is higher in B horizons and soils are classified as Danvers series. Both components exhibit high calcium carbonate below the A horizon (Soil Web; NRCS OSD website; Fig. 2b) and we refer to them here as calcareous loam soils. The largest fraction of remaining area $(7 \%)$ is made up of shalederived soils that are rich in gypsum (calcium and sulfate) and sodium (supplemental materials).

\subsection{Water sample collection}

We selected water sampling locations to capture nitrate flux and associated major ion chemistry along flow paths from soils to groundwater and surface water. Optimal sample site locations were developed in conversation with local producers and community members (supplemental materials), and through observations 


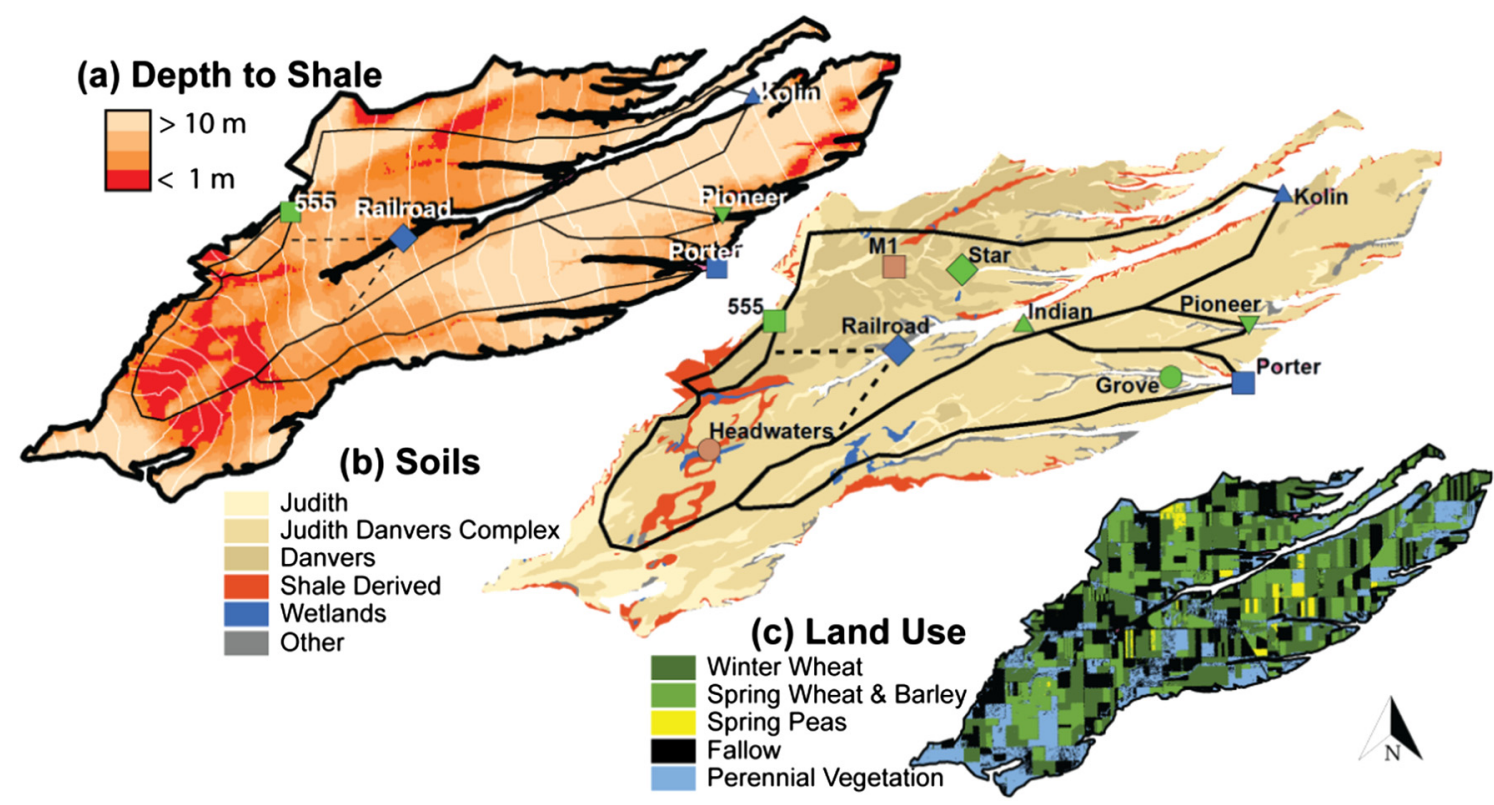

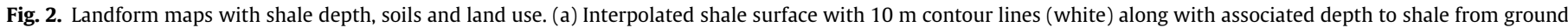

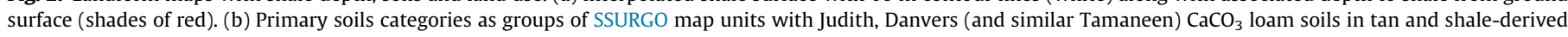

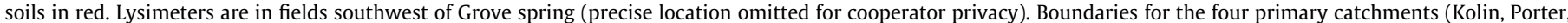

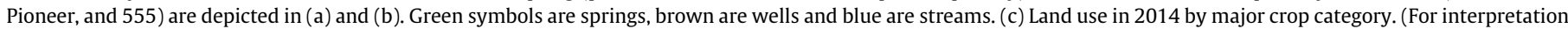
of the references to colour in this figure legend, the reader is referred to the web version of this article.)

made during early sampling of the stream network (Miller, 2013). All water samples were field filtered at $0.45 \mu \mathrm{m}$, transported cold, and frozen prior to analysis, except for inorganic and organic carbon analysis, which occurred on never-frozen samples within two weeks of sample collection. See supplemental materials for a more detailed description of water sample collection methods.

Soil water sampling with porous cup tension lysimeters (PTFE/ silica; Prenart Equipment; Frederiksberg, Denmark) was conducted within privately owned/managed fields (ca. 80 acres; 32 ha). Installation/sampling was coordinated with cooperating farmers to minimize disruption of farming operations and ensure that samples represented the outcome of uninterrupted standard field-scale farming practices. Eighteen lysimeters were installed in calcareous soils (near Grove spring, Fig. 2b) on the Moccasin terrace and in similar nearby soils under the same management. Lysimeters were installed in fine textured material just above the gravely horizons (50 to $100-\mathrm{cm}$ depth) below undisturbed upper soil horizons. During seasons when soil water content was relatively high, lysimeters were visited one to three times per month and an internal tension of approximately $-100 \mathrm{kPa}$ was applied with a hand pump to sample soil water. Only data from samples greater than $2.0 \mathrm{~mL}$, collected within $48 \mathrm{~h}$ of pressurization are reported here. Excluding samples smaller than $2.0 \mathrm{~mL}$ removed from consideration soil water nitrate concentrations during drier conditions when leaching was less likely to be occurring. Lysimeter samples were separated into crop rotation categories based on land use in the preceding growing season (ending 15 October). For example, a sample collected any time between 15 October 2012 and 14 October 2013 is categorized as post-fallow or post-grain depending on whether the field was in fallow or grain during the 2012 growing season.

Groundwater sampling sites (Fig. 2b) were wells and springs selected to represent subsurface contributing areas with a range of mean groundwater flow path lengths and different overlying soil types. Delineation of subsurface contributing areas to sampling sites was based on flow directions estimated from surface topography (Miller, 2013). Nitrate data from Montana Department of Agri- culture (MDA) monitoring well M1 for the period 1994-2015 (two samples per year) were obtained from MDA (unpublished data; Schmidt and Mulder, 2010; Schmidt, 2009) and historic water level data were downloaded from the Montana Bureau of Mines and Geology (MBMG) Groundwater Information Center (MBMG, 2016).

Surface water was sampled in order to capture $\mathrm{N}$ export from the landscape. Louse and Porter Creeks were identified as the largest streams draining the terrace (Fig. 2b). We sampled Porter Creek at a single location at the outlet from the terrace (Porter site). Louse Creek was sampled at two locations: at an upstream location draining the higher elevations of the terrace (Railroad site) and at the outlet from the terrace (Kolin site). Water sampling at ground and surface water sites was conducted 12-15 times per year during 2012-2014. Five of the sites were established in 2012 (Miller, 2013) and the other five were established in 2013 (Table 2).

\subsection{Water sample analysis and major ion composition}

Chemical analysis of all water samples was conducted in the Department of Land Resources and Environmental Sciences Environmental Analytical Laboratory (EAL) on the MSU campus. Major anions (chloride, nitrate, sulfate) were analyzed by ion chromatography (Dionex, ICS-2100, AS18 column), major cations and total sulfur by inductively coupled plasma-optical emission spectroscopy (Perkin Elmer, 5300 DV), dissolved organic and inorganic carbon by combustion (Shimadzu, TOC VCSH), and nitrate additionally by cadmium reduction and colorimetry (Lachat, QuickChem 8500; Seal, QuAAtro). See supplemental materials for detailed analytical methods and data quality assurance procedures. Differences in major ion composition were used to assess connectivity among soil, ground, and surface waters. In order to infer source waters based on relative variations in major ion composition of a given sample, dilution effects were removed by calculating ion ratios, which represent the fraction of the molar concentration of an individual ion relative to the summed molarity for all major ions. Variation in ion ratios among sites was evaluated using principle component analysis (PCA) conducted within R sta- 
tistical software with the prcomp function, with data scaled to unit variance ( $\mathrm{R}$ version 2.15.2; The $\mathrm{R}$ Foundation for Statistical Computing, Vienna, Austria). For the PCA, ion ratios were aggregated as annual means within sites for the 2013-14 intensive data collection period. Tests for statistical difference in concentrations for different sites or domains (i.e. soil versus groundwater) were conducted with paired Kruskal-Wallis rank sum test using kruskal.test function within $\mathrm{R}$ statistical software ( $\mathrm{R}$ version 2.15.2; The R Foundation for Statistical Computing, Vienna, Austria).

\subsection{Groundwater catchment delineation, discharge, stream baseflow and area-normalization}

Groundwater catchments were delineated to allow normalization of volumetric stream flow observations from the Porter and Kolin sites to the area of their respective drainage and to subsequently produce leaching estimates (described in Section 2.5). We interpret area-normalized stream flow at low-flow conditions as an indicator of baseflow yield and subsequently groundwater recharge, assuming that the change in storage in groundwater over the three-year study was negligible compared to the total volume of recharge or discharge over that time.

Area normalizations are based on annually cultivated catchment area alone, and the perennially vegetated catchment area is therefore excluded. See Supplemental Fig. 1 for a conceptual representation of this area normalization approach. This approach produces more accurate areal recharge rates for the cultivated soils, considering research that suggests recharge rates are much higher through annually cultivated soils than through perennially vegetated soils (Scanlon et al., 2005). Because we assume no recharge through perennially vegetated soils, there is some possibility of over-estimating recharge rates through annually cultivated soils during the limited time when water content in perennially vegetated soils exceeds field capacity. Nitrate leaching rates for annually cultivated soils are estimated with the same areanormalization approach, but are less subject to over-estimation. This approach assumes (Section 2.5; Supplemental Fig. 1) that virtually all nitrate in groundwater comes from annually cultivated soils. This assumption is supported by both higher recharge rates driving more leaching and higher nitrate concentrations in annually cultivated soils relative to perennially vegetated soils. Consistent with this assumption, soil nitrate concentrations in the top 15 $\mathrm{cm}$ in three perennially vegetated fields were approximately an order of magnitude lower than those in adjacent annually cultivated fields during the fallow phase of the crop rotation (data now shown).

Delineations of groundwater catchments were derived from surface-derived topographic divides and subsurface divides determined by the topographic surface of underlying shales. Delineation by surface topography was based on a one third arc-second $(\sim 10$ m) National Elevation Dataset (USGS, 2012) digital elevation model (DEM) processed in ArcMap Spatial Analyst using the Flow Direction and Watershed tools based on the sample site locations. The shale surface DEM was estimated in ArcMap by kriging shale surface elevations from well logs, geologic maps coupled with aerial imagery, and mapped locations of shale-derived soil series (ordinary spherical semivariogram kriging model; supplemental materials). Ground-surface- and shale-surface-derived catchment delineations were manually combined based on assessment of the most likely driver of flow direction in a given area. The ground-surface-derived delineation was selected where shale was near the surface and where the shale-surface-delineation was ambiguous. The shale-surface-delineation was selected in places where shale topography was unambiguous and departed from ground surface shape (most notably around the Spring 555 sample site; Fig. 2A).
Stream discharge $\left(\mathrm{Q}, \mathrm{m}^{3} \mathrm{~s}^{-1}\right)$ at the Porter and Kolin sites was measured manually during water sampling visits using the velocity cross-section method with a Marsh McBirney FloMate electromagnetic flow meter. In 2013, manual staff gages were installed along with stilling wells containing capacitance rod stage recorders (TruTrack, Inc.). For periods prior to stage recorder installation and when ice affected stage, daily $\mathrm{Q}$ was estimated using linear interpolation between the measured or modeled values bracketing the period.

We quantified aquifer efflux by estimating baseflow with a simple manual hydrograph separation method, using linear interpolation between inflection points identified on the rising and falling limbs of the hydrograph. This manual linear approach was used rather than a more objective approach (e.g., Lyne and Hollick, 1979; Lim et al., 2005) to ensure that allocation of flow to the groundwater source was conservatively low during high flow periods in March-June when flow data were less reliable. Selection of methods producing conservatively low values provides confidence that nitrate flux estimates produced from baseflow estimates represent a lower bound on nitrate leaching losses.

\subsection{Nitrate loading to ground/surface water and leaching rates}

To estimate cultivated soil nitrate load $\left(\mathrm{kg} \mathrm{N} \mathrm{yr}^{-1}\right)$ to the riparian corridor (NLRC) prior to hypothesized riparian losses, each daily mean aggregate groundwater nitrate concentration (mean across seven groundwater sites) was multiplied by daily stream baseflow. These loads were area-normalized to the annually cultivated land area within each catchment (described in section 2.4 and Supplemental Fig. 1) in order to estimate leaching rates ( $\mathrm{kg}$ $\mathrm{N} \mathrm{ha}^{-1} \mathrm{yr}^{-1}$ ).

Daily mean aggregate groundwater nitrate concentrations used for load calculations were derived by first calculating monthly mean concentrations for each of the seven groundwater sites. Monthly mean values for the sites were then averaged to produce the monthly mean aggregate groundwater values and linear interpolation between these values produced the daily mean aggregate groundwater concentrations. During the intensive April 2013 to September 2014 sampling period, the seven groundwater sites selected to represent variability in terrace groundwater were included in this calculation. Before and after the intensive sampling period, two groundwater sites were included in the monthly mean aggregate groundwater concentration. Uncertainty in the monthly mean aggregate groundwater nitrate concentration was assessed using residual differences between the monthly mean aggregate groundwater values and monthly means for the individual sites during the 2013-14 high intensity sampling period. A Monte Carlo ensemble of groundwater concentration time series was created with 1000 randomly generated realizations from this distribution. The ensemble of groundwater concentrations in combination with daily stream baseflow values determined the ensemble of loads that provide some constraint on uncertainty in daily and annual mean NLRC estimates. Descriptive statistics (i.e. $2.5 \%$ and $97.5 \%$ quantiles) from the resulting Monte Carlo ensembles of concentrations, daily loads, and time-aggregated loads provide a rough estimate of how error in characterizing a single aggregate nitrate concentration from the observed spatial variation in groundwater may propagate to uncertainty in the total load estimates from the terrace.

To estimate nitrate- $\mathrm{N}$ losses from the riparian corridor, stream concentrations were subtracted from mean groundwater concentrations during periods when the majority of stream flow was originating from longer-term storage. This calculation was conducted for stream concentrations and the set of groundwater concentrations collected on the same sampling trip. 


\subsection{Groundwater residence time}

We sampled for apparent groundwater age using ${ }^{3} \mathrm{H}-{ }^{3} \mathrm{He}$ (Cook and Solomon, 1997) in May 2014 at the M1 monitoring well and at two springs (Indian and Grove sites). Gas sampling was conducted with copper tube diffusion samplers deployed in the well and in flow-through buckets at the orifice of the springs, with $24 \mathrm{~h}$ equilibration time before being crimp sealed (Sanford et al., 1996). At the time of gas sampler deployment, 1-L polypropylene bottles were filled with water for associated ${ }^{3} \mathrm{H}$ analysis. Gas and water samples were shipped to the University of Utah Stable Isotope Laboratory for analysis. Tritium analysis was performed using a Helix SFT sector-field mass spectrometer with the helium ingrowth method (Clarke et al., 1976).

Groundwater turnover time was also estimated based on a fully mixed reservoir assumption, dividing the estimated total volume of the groundwater reservoir $\left[\mathrm{L}^{3}\right]$ by the total discharge from that reservoir $\left[\mathrm{L}^{3} \mathrm{~T}^{-1}\right]$. Steady state aquifer outflow is estimated as the average annual baseflow discharge for each catchment over the three-year study (Section 2.4). Aquifer volumes for each catchment were estimated from the product of catchment area (Section 2.4), specific yield of 0.3 (Anderson and Woessner, 1992), and saturated thickness. Saturated thickness was estimated by first calculating the thickness of gravel overlying shale, as the shale surface DEM subtracted from the ground surface DEM. The fraction of the gravel that was saturated was estimated using values observed in seven well logs (MBMG, 2016) within terrace boundaries where shale depth and depth of water below ground surface were available.

\section{Results}

\subsection{Catchment delineation and soil type composition}

The Kolin groundwater catchment area is the largest within the landform at 9670 ha (37\% terrace area), followed by Porter (3630 ha and 14\%), Pioneer spring (750 ha, 3\%) and Spring 555 (320 ha, $1 \%$; Fig. 2a-b, Table 1). For three of these four catchments (Kolin, Porter, Pioneer) surface topography based delineation was not notably different from the shale surface approach, while for Spring 555 the catchment area was much larger ( 500\%) based on infer- ence from the shale surface. The four groundwater catchment areas combined (Kolin, Porter, Pioneer, Spring 555) capture 55\% of the terrace area, indicating that the majority of water leaving the terrace is characterized by the ion chemistry data presented here. Shale soils compose $13 \%$ of the Louse Creek catchment above Railroad and $8 \%$ of the catchment above Kolin (Fig. 2b, Table 1). The Spring 555 catchment has the highest fraction of shale-derived soils (16\%) while Porter creek catchment has no shale-derived soil.

\subsection{Nitrate concentrations in soil water and groundwater}

The mean nitrate- $\mathrm{N}$ concentration observed in M1 during the three-year study (18.6 $\left.\pm 6.7 \mathrm{mg} \mathrm{L}^{-1}\right)$ was generally consistent with predictions from the increasing trend in the well from ca. 10 to ca. $20 \mathrm{mg} \mathrm{L}^{-1}$ during the $1994-2015$ observation period (Fig. 3). The three-year mean for M1 was also not significantly different (Kruskal-Wallis, $\mathrm{p}=.20$ ) from the aggregate mean concentration for the other six groundwater sites over the three-year period $\left(20.9 \pm 6.6 \mathrm{mg} \mathrm{L}^{-1}\right)$. However, the mean concentration in M1 for $2014\left(9.9 \pm 4.7 \mathrm{mg} \mathrm{L}^{-1}\right)$ was notably lower than for 2012 $\left(21.4 \pm 0.9 \mathrm{mg} \mathrm{L}^{-1}\right)$ and $2013\left(23.4 \pm 0.9 \mathrm{mg} \mathrm{L}^{-1}\right)$ and lower than mean concentration in aggregate terrace groundwater for 2014 (17.1 $\mathrm{mg} \mathrm{L}^{-1}$, Table 2). The lower 2014 mean concentration in M1 was confirmed to be a local dilution event based on a corresponding change in specific conductance. This type of transient dilution is also suggested by the historic data in the form of occasional concentrations lower than the overall increasing trend (Fig. 3). Lower nitrate concentrations in M1 consistently occur during the January-July period when snow melt and the heaviest seasonal precipitation occurs, and only one of the other groundwater sites (Pioneer) displays a spring dilution pattern of similar magnitude. The fact that dilution effects are relatively localized in time and space suggests that they do not have a substantial influence on the long-term state of the aquifer. Given the seasonal timing of these transient dilution events, the long-term trend in aquifer status was assessed with only the concentrations for August to December samples. Concentrations during this period tend to be more stable and presumably less subject to temporary dilution during large recharge events. Regression of nitrate concentrations from this smaller data set with time $\left(r^{2}=0.79, p<.05\right.$, Fig. 3)

Table 1

Terrace and Catchment Characteristics.

\begin{tabular}{|c|c|c|c|c|c|c|}
\hline & Terrace & Spr555 & Pioneer & Porter & Kolin & Railroad" \\
\hline Total area $\left(\mathrm{km}^{2}\right)$ & 261.4 & 3.2 & 7.5 & 36.3 & 96.7 & 36.4 \\
\hline Total area (ha) & 26,140 & 320 & 750 & 3630 & 9670 & 3640 \\
\hline Terrace area (\%) & 100 & 1 & 3 & 14 & 37 & 14 \\
\hline Mean depth to shale (m) & 7.2 & 4.6 & 11.2 & 8.3 & 5.7 & 3.1 \\
\hline \multicolumn{7}{|l|}{ Aquifer Characteristics } \\
\hline Saturated Thickness (m) & 3.6 & 2.3 & 5.6 & 4.2 & 2.9 & 1.6 \\
\hline Water Volume. $\left(\mathrm{m}^{3} \mathrm{ha}^{-1}\right)$ & 10,800 & 6900 & 16,800 & 12,450 & 8550 & 4650 \\
\hline \multicolumn{7}{|l|}{ Soils } \\
\hline Judith (\%) & 10 & 0 & 10 & 10 & 5 & 3 \\
\hline Judith Danvers (\%) & 62 & 7 & 88 & 83 & 59 & 68 \\
\hline Danvers (\%) & 17 & 77 & 0 & 1 & 25 & 11 \\
\hline Shale derived (\%) & 7 & 16 & 0 & 0 & 8 & 13 \\
\hline Wetland (\%) & 1 & 0 & 0 & 2 & 1 & 3 \\
\hline Other $(\%)$ & 3 & 0 & 2 & 4 & 2 & 2 \\
\hline \multicolumn{7}{|l|}{ Land Use } \\
\hline Annual Cultivation (\%) & 72 & 93 & 92 & 70 & 77 & 71 \\
\hline Annual Cultivation (ha) & 18,821 & 298 & 690 & 2541 & 7446 & 2584 \\
\hline Fallow $^{* * *}(\%)$ & 25 & 50 & 18 & 26 & 25 & 31 \\
\hline Perennial (\%) & 25 & 3 & 5 & 25 & 19 & 25 \\
\hline Other (\%) & 3 & 4 & 3 & 5 & 4 & 3 \\
\hline
\end{tabular}

\footnotetext{
* Railroad is a headwater sub-catchment within Kolin catchment.

** Aquifer characteristics assume $50 \%$ of gravel thickness is saturated. As a result, saturated thickness is equal to vadose zone thickness. Water volume assumes specific yield of 0.3 .

Fallow is calculated as percent of annual cultivation area.
} 


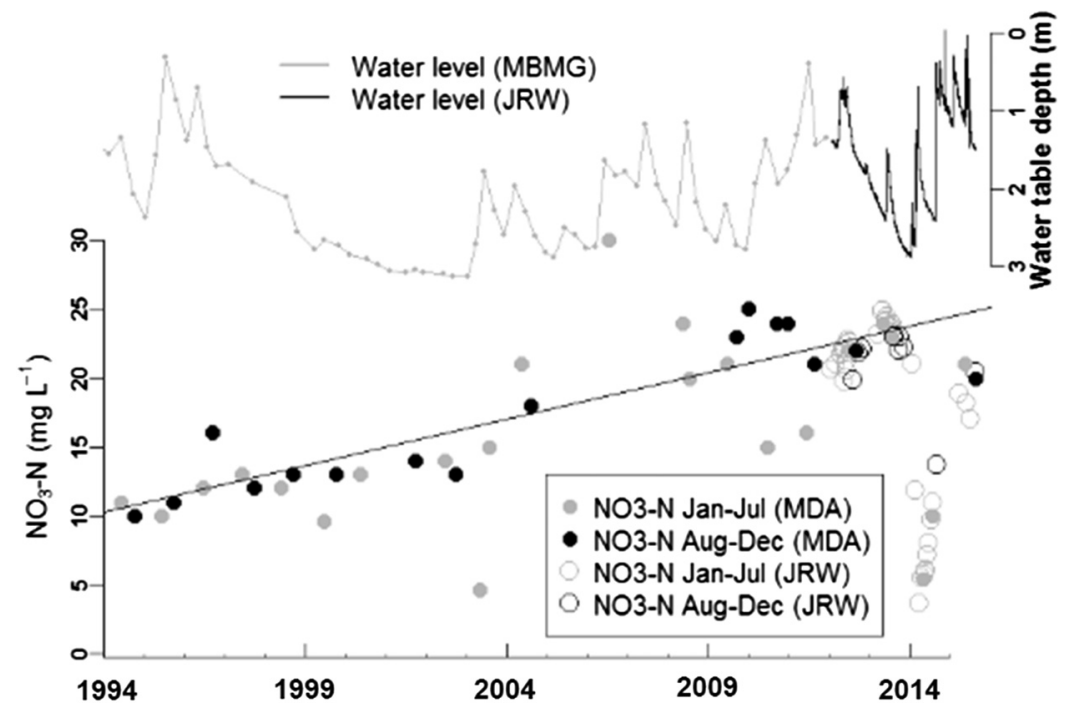

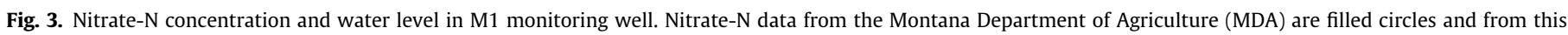

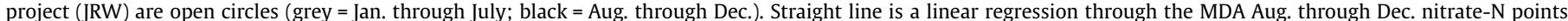

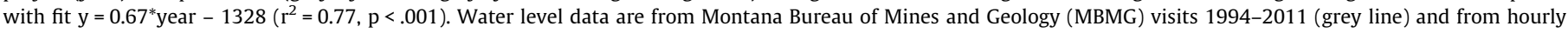
transducer data from this project (black line).

Table 2

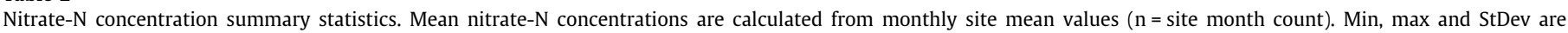

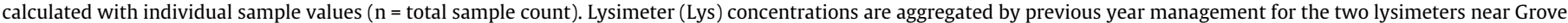

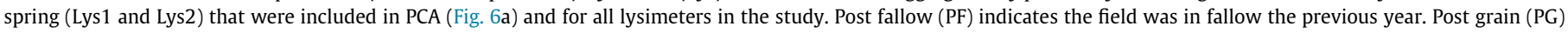
indicates the field was in grain the previous year.

\begin{tabular}{|c|c|c|c|c|c|c|c|}
\hline Site & Period & $\begin{array}{l}\text { Mean } \\
\left(\mathrm{mg} \mathrm{L}^{-1}\right)\end{array}$ & $\begin{array}{l}\text { StDev } \\
\left(\mathrm{mg} \mathrm{L}^{-1}\right)\end{array}$ & $\begin{array}{l}\operatorname{Min} \\
\left(\mathrm{mg} \mathrm{L}^{-1}\right)\end{array}$ & $\begin{array}{l}\operatorname{Max} \\
\left(\mathrm{mg} \mathrm{L}^{-1}\right)\end{array}$ & $\begin{array}{l}\text { Mean n } \\
\text { (count) }\end{array}$ & $\begin{array}{l}\text { Min, Max, StDev n } \\
\text { (count) }\end{array}$ \\
\hline \multicolumn{8}{|l|}{ Lysimeters } \\
\hline Lys1 & 2013 PG & 10.9 & 1.8 & 7.9 & 12.4 & 2 & 5 \\
\hline Lys1 & $2014 \mathrm{PF}$ & 8.8 & 0.8 & 8.3 & 9.4 & 2 & 2 \\
\hline Lys2 & 2013 PG & 10.4 & 1.1 & 9.2 & 11.4 & 2 & 3 \\
\hline Lys2 & $2014 \mathrm{PF}$ & 61.0 & NA & 61.0 & 61.0 & 1 & 1 \\
\hline All Lys & $\mathrm{PF}$ & 25.4 & 14.0 & 0.4 & 61.0 & 20 & 30 \\
\hline All Lys & PG & 11.6 & 7.7 & 0.2 & 42.9 & 35 & 52 \\
\hline All Lys (Aggregate) & PF \& PG & 16.6 & 13.1 & 0.2 & 61.0 & 55 & 82 \\
\hline \multicolumn{8}{|l|}{ Groundwater } \\
\hline Headwaters & 2013 & 30.7 & 1.4 & 28.4 & 32.3 & 8 & 14 \\
\hline Headwaters & 2014 & 29.0 & 2.6 & 25.0 & 33.5 & 7 & 10 \\
\hline Spr555 & 2013 & 18.7 & 1.9 & 15.6 & 20.8 & 8 & 14 \\
\hline Spr555 & 2014 & 15.4 & 3.3 & 12.2 & 24.5 & 8 & 11 \\
\hline M1 & 2012 & 21.4 & 0.9 & 19.8 & 22.8 & 9 & 16 \\
\hline M1 & 2013 & 23.4 & 0.9 & 22.0 & 24.9 & 9 & 15 \\
\hline M1 & 2014 & 9.9 & 4.7 & 3.6 & 21.0 & 8 & 13 \\
\hline Star & 2013 & 25.2 & 1.0 & 23.2 & 26.9 & 8 & 14 \\
\hline Star & 2014 & 18.4 & 1.4 & 16.1 & 19.5 & 5 & 5 \\
\hline Indian & 2013 & 18.7 & 1.2 & 17.0 & 20.6 & 8 & 14 \\
\hline Indian & 2014 & 19.3 & 1.6 & 15.2 & 21.7 & 8 & 26 \\
\hline Grove & 2012 & 24.4 & 1.5 & 21.5 & 26.5 & 7 & 13 \\
\hline Grove & 2013 & 24.2 & 0.7 & 22.9 & 25.3 & 8 & 14 \\
\hline Grove & 2014 & 23.3 & 1.4 & 20.6 & 24.9 & 8 & 10 \\
\hline Pioneer & 2013 & 17.6 & 4.0 & 9.6 & 22.6 & 7 & 13 \\
\hline Pioneer & 2014 & 5.0 & 2.3 & 1.5 & 8.7 & 7 & 10 \\
\hline Aggregate GW & 2012 & 22.7 & 2.1 & 19.8 & 26.5 & 16 & 29 \\
\hline Aggregate GW & 2013 & 22.7 & 4.7 & 9.6 & 32.3 & 56 & 98 \\
\hline Aggregate GW & 2014 & 17.1 & 7.7 & 1.5 & 33.5 & 51 & 85 \\
\hline Aggregate GW & $2012-14$ & 20.4 & 6.4 & 1.5 & 33.5 & 123 & 212 \\
\hline \multicolumn{8}{|l|}{ Surface Water } \\
\hline Porter & 2012-14 & 19.3 & 1.9 & 15.5 & 23.0 & 24 & 40 \\
\hline Railroad & $2012-14$ & 12.1 & 3.7 & 6.5 & 18.0 & 27 & 58 \\
\hline Kolin & 2012-14 & 10.0 & 2.2 & 5.7 & 15.4 & 26 & 58 \\
\hline
\end{tabular}

indicates nitrate- $\mathrm{N}$ concentrations have generally increased by 0 . $67 \pm 0.09 \mathrm{mg} \mathrm{L}^{-1} \mathrm{yr}^{-1}$ in the well for the past two decades.

The range of nitrate- $\mathrm{N}$ concentrations observed in groundwater (1.5-33.5 $\mathrm{mg} \mathrm{L}^{-1}$ ) was approximately half that observed in lysime- ters ( $\left.<1-61 \mathrm{mg} \mathrm{L}^{-1}\right)$, suggesting an averaging effect in groundwater with respect to incoming soil leachate concentration. However, the aggregate mean groundwater nitrate concentration $(20.4 \pm 6.4 \mathrm{mg}$ $\left.\mathrm{L}^{-1}\right)$ was significantly higher $(\mathrm{p}<.05)$ than the aggregate mean 
lysimeter nitrate concentration $\left(16.6 \pm 13.1 \mathrm{mg} \mathrm{L}^{-1}\right)$. When lysimeter samples were separated based on phase of cropping cycle, post-fallow concentrations $\left(25.4 \pm 14.0 \mathrm{mg} \mathrm{L}^{-1}\right)$ were significantly higher $(\mathrm{p}<.05)$ than post-grain concentrations $\left(11.6 \pm 7.7 \mathrm{mg} \mathrm{L}^{-1}\right)$. Mean groundwater nitrate-N concentration was intermediate between mean lysimeter concentrations grouped by crop phase (Fig. 4). Groundwater concentration was significantly higher $(\mathrm{p}<.05)$ than lysimeter concentrations post-grain, but not significantly different $(\mathrm{p}=.08)$ from lysimeter concentrations post-fallow. These results agreed with expectations in the simple sense that aggregate groundwater nitrate concentration was not lower than aggregate lysimeter concentration, but concentrations were similar (not significantly different) only when cropping stage was considered.

\subsection{Major ion composition of terrace waters and hydrologic connectivity}

The highest total ion concentrations observed in ground and surface waters were in the well at the Headwaters site (20.9 $\mathrm{mM}$ ) and the spring at the 555 site $(17.8 \mathrm{mM})$, (Table 3, Fig. 5). These molar concentrations are approximately twice that of the five other groundwater sites. Higher molarities at the Headwaters site are attributable mostly to higher sodium $\left(\mathrm{Na}^{+}\right)$concentrations, but sulfate is notably higher at both the Headwaters and 555 sites relative to the other groundwater sites. The Railroad site has the highest total ion concentration of the surface water sites (16.8 $\mathrm{mM})$.

A PCA of the molar ratios resulted in $77 \%$ of the total variation in composition explained by the first two components ( $\mathrm{PC} 1=58 \%$, PC2 $=19 \%$ ). Analytes contributing the most loading on PC1 were sulfate $\left(\mathrm{SO}_{4}^{2-}\right)$ and sodium on the negative side and calcium $\left(\mathrm{Ca}^{2+}\right)$ and bicarbonate $\left(\mathrm{HCO}_{3}^{-}\right)$on the positive side (Fig. 6a, Table 4). Analytes with the most important loading on PC2 are nitrate on the positive side and magnesium $\left(\mathrm{Mg}^{2+}\right)$ and bicarbonate on the negative side.

Sampling sites with the lowest mean PC1 scores (higher sodium and sulfate molar ratios) are Spring 555 and Headwaters site, which are located in the higher elevations of the terrace (Fig. 2 Table 4), with higher occurrence of shale soils. The Railroad catchment, which encompass the shale soil areas in the upper half of the terrace, also has low PC1 scores. The Kolin catchment encompasses the Railroad catchment but also drains extensive calcareous soils downstream and has a higher PC1 score than Railroad. On the other extreme of PC1, the highest scores (higher proportion calcium and bicarbonate) are for the lysimeter soil water samples and Pioneer Spring, followed by the other springs draining the downgradient half of the terrace where calcareous soils are dominant. Porter Creek, draining much of the southern regions of the terrace, has a PC1 score similar to Grove and Indian springs, which drain that portion of the terrace where very little shale soil is present. This general alignment of PC1 score and prevalence of shale soil is consistent across the terrace, demonstrated by a strong negative relationship (slope $=-0.25 ; \mathrm{r} 2=0.94 ; \mathrm{p}<.05$ ) between percent shale soil within a catchment and PC1 score in surface water (Fig. 6b). Alignment of water sample site PC1 scores (sodium and sulfate versus calcium $^{+}$and bicarbonate) with the extent of shale soil versus calcareous soil upgradient agrees with our prediction that ground and surface water chemistry will uniquely reflect chemistry of soils within a catchment.

Differences in nitrate concentration are the next most notable driver of variation in ion ratios, reflected in PC2 scores. Soil nitrate concentrations are highly dynamic, which is why lysimeter samples produced both the highest and lowest PC2 scores. Higher nitrate concentrations in groundwater relative to surface water are evident in groundwater sites generally having higher PC2 scores, a finding consistent with our prediction of lower surface water nitrate after riparian losses.

\subsection{Stream discharge, groundwater levels and recharge}

Kolin and Porter Creek catchment discharges (Fig. 7d-e; Table 4) experienced annual peaks between March and June across the study period, coincident with peak water levels in the M1 well (Fig. 7a-b). Peak groundwater and stream discharge levels aligned with timing and magnitude of April-June precipitation in 2012 and

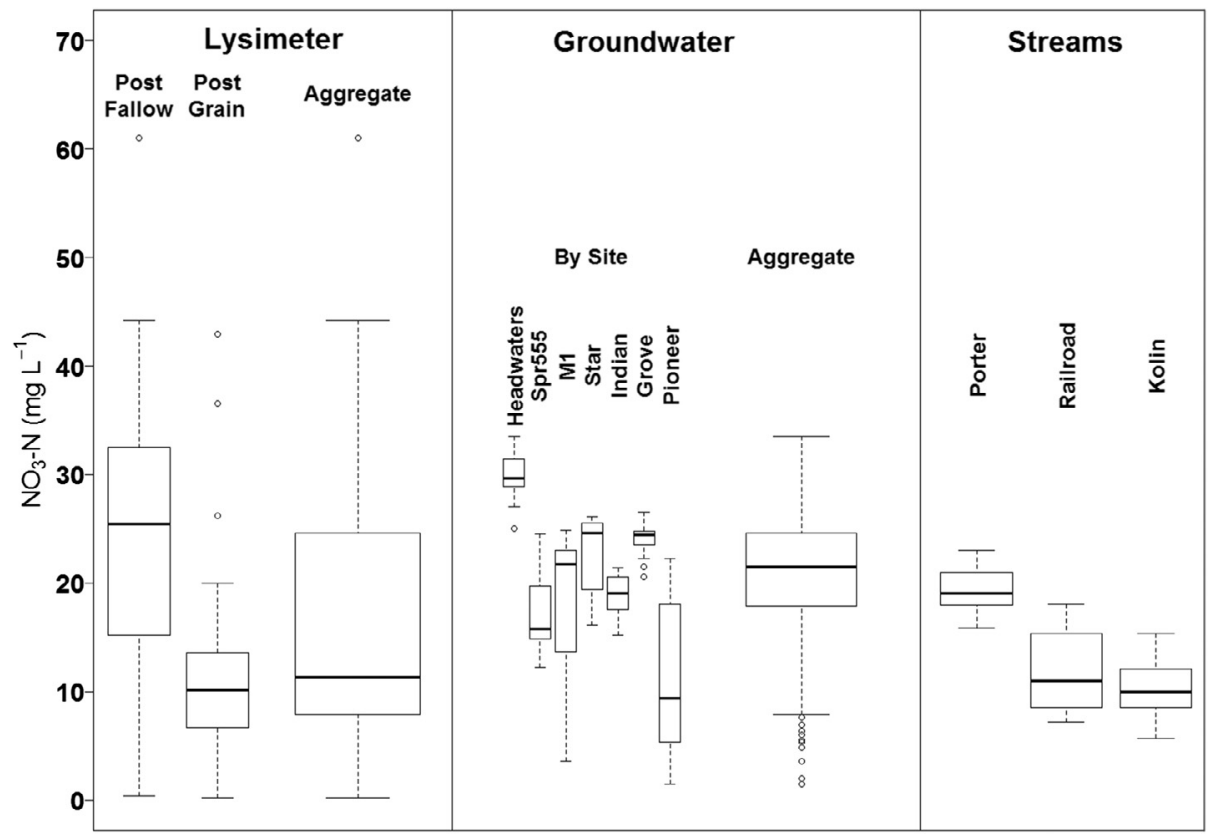

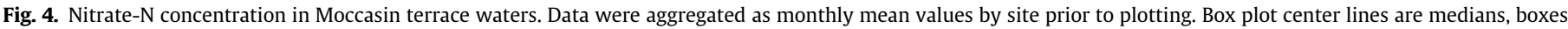
are 25 th and 75 th percentiles, whiskers extend to most extreme data point that is no more than 1.5 times the interquartile range away from the box. 
Table 3

Annual mean major ion concentrations (mM) and principal component (PC) scores. Major ion concentrations for individual samples are included in supplemental materials.

\begin{tabular}{|c|c|c|c|c|c|c|c|c|c|c|c|c|c|}
\hline variable & $\mathrm{yr}$ & $\mathrm{HW}^{*}$ & Spr555 & M1 & Star & Indian & Grove & Pion. & Porter & Railrd & Kolin & Lys1 & Lys2 \\
\hline $\mathrm{Ca}$ & 13 & 0.7 & 1.1 & 1.7 & 1.3 & 1.2 & 1.1 & 2.0 & NA & 1.4 & 1.4 & 1.5 & 2.6 \\
\hline $\mathrm{Ca}$ & 14 & 1.2 & 1.4 & 1.3 & 1.4 & 1.3 & 1.2 & 2.0 & 1.2 & 1.7 & 1.3 & 1.0 & 2.3 \\
\hline $\mathrm{Mg}$ & 13 & 1.8 & 2.3 & 1.8 & 1.3 & 1.4 & 1.3 & 0.6 & NA & 2.4 & 1.8 & 2.5 & 0.8 \\
\hline $\mathrm{Mg}$ & 14 & 2.1 & 2.0 & 1.6 & 1.3 & 1.4 & 1.4 & 0.5 & 1.5 & 2.1 & 1.6 & 1.8 & 0.8 \\
\hline $\mathrm{Na}$ & 13 & 7.4 & 5.3 & 2.0 & 1.3 & 0.8 & 1.8 & 1.5 & NA & 3.7 & 2.0 & 0.5 & 0.5 \\
\hline $\mathrm{Na}$ & 14 & 6.9 & 4.3 & 1.4 & 1.3 & 1.0 & 1.5 & 1.1 & 0.9 & 3.6 & 1.9 & 0.5 & 0.7 \\
\hline NO3-N & 13 & 2.2 & 1.3 & 1.7 & 1.8 & 1.3 & 1.7 & 1.2 & NA & 0.7 & 0.7 & 0.9 & 0.8 \\
\hline NO3-N & 14 & 2.1 & 1.3 & 0.8 & 1.4 & 1.5 & 1.7 & 0.5 & 1.3 & 0.6 & 0.5 & 0.8 & 3.2 \\
\hline $\mathrm{HCO} 3$ & 13 & 6.8 & 6.1 & 5.0 & 4.4 & 4.1 & 4.1 & 5.2 & NA & 6.2 & 4.9 & 7.0 & 6.4 \\
\hline HCO3 & 14 & 7.0 & 5.9 & 4.2 & 4.6 & 4.1 & 4.2 & 5.3 & 3.8 & 6.7 & 4.9 & 5.0 & 3.4 \\
\hline S & 13 & 1.7 & 2.8 & 1.1 & 0.3 & 0.5 & 0.3 & 0.2 & NA & 2.3 & 1.5 & 0.2 & 0.1 \\
\hline S & 14 & 2.1 & 2.0 & 1.2 & 0.4 & 0.5 & 0.3 & 0.1 & 0.3 & 2.1 & 1.2 & 0.2 & 0.2 \\
\hline sum & 13 & 20.6 & 18.8 & 13.3 & 10.4 & 9.4 & 10.3 & 10.9 & NA & 16.7 & 12.4 & 12.6 & 11.4 \\
\hline sum & 14 & 21.3 & 16.9 & 10.5 & 10.3 & 9.8 & 10.2 & 9.5 & 9.1 & 16.8 & 11.5 & 9.4 & 10.6 \\
\hline PC1 & 13 & -2.7 & -3.0 & -0.3 & 0.9 & 0.8 & 0.2 & 1.6 & NA & -2.1 & -1.1 & 1.7 & 3.1 \\
\hline PC1 & 14 & -2.5 & -2.1 & -0.6 & 0.8 & 0.7 & 0.5 & 2.3 & 0.7 & -1.7 & -0.8 & 1.4 & 2.3 \\
\hline PC2 & 13 & 1.3 & 0.2 & 0.3 & 0.6 & -0.4 & 0.8 & 1.1 & NA & -0.7 & -0.9 & -2.6 & -0.1 \\
\hline PC2 & 14 & 1.0 & 0.3 & -0.8 & 0.1 & 0.0 & 0.5 & 0.1 & -0.4 & -0.6 & -1.0 & -2.3 & 3.4 \\
\hline
\end{tabular}

" Headwaters.

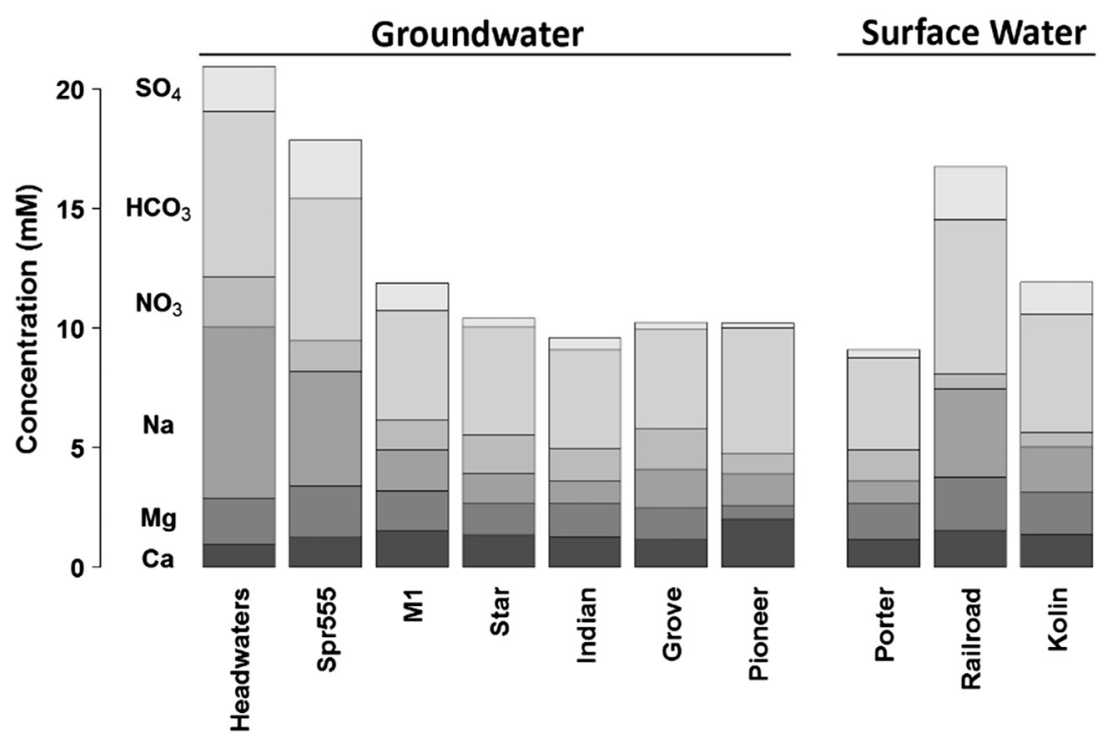

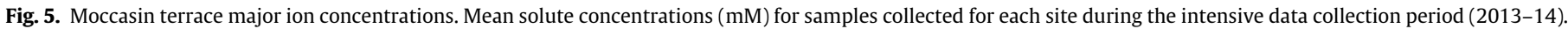
See supplemental materials for individual sample concentration data.

2013, while peaks in 2014 coincided with snow melt and rain-onsnow events in February-March. On Aug. 23rd of 2014, $110 \mathrm{~mm}$ of rain fell at the CARC Agrimet station on a single day, amounting to more than twice the previous maximum daily precipitation (41 $\mathrm{mm}$ on 5/24/2011) since installation of the station in 2001.

Annual average baseflow for both streams (Table 5) was highest in 2012 following high annual precipitation in 2011 and baseflow was lowest in 2013 after low annual precipitation in 2012. The lowest measured baseflow in Louse Creek was just before the 23 August 2014 rain event, which brought groundwater levels and Louse Creek flows back up to levels similar to early 2012. While groundwater and stream discharge respond to precipitation on a timescale of days to months, influence of previous year precipitation on average annual baseflow suggests that stream discharge is integrating recharge rates across the current and previous year. Therefore, while area-normalized annual average baseflows are presented (Table 5) as an estimate of annual recharge, these may be over- or under-estimated due to baseflow contributions from inter-annual storage. Therefore, we also report the three-year mean values $\left(\right.$ Kolin $=54 \mathrm{~mm} \mathrm{yr}^{-1}$, Porter $=87 \mathrm{~mm} \mathrm{yr}^{-1}$ ) as an esti- mate of average annual recharge that is less influenced by interannual storage.

\subsection{Nitrate leaching rates and riparian losses}

Daily mean NLRC values for Kolin (Fig. $7 \mathrm{f} ; 11.1 \pm 0.3 \mathrm{~kg} \mathrm{~N}^{-1}$ $\mathrm{yr}^{-1}$ ) are, on average, $60 \%$ of those for Porter (Fig. $7 \mathrm{~g} ; 18.4 \pm 0.4 \mathrm{~kg}$ $\mathrm{N} \mathrm{ha}^{-1} \mathrm{yr}^{-1}$ ). The same aggregate groundwater nitrate concentrations are used to calculate the NLRC values for both catchments, so the different NLRC values stem from differences in areanormalized baseflow between the catchments. Uncertainty in concentration and NLRC values (gray shading Fig. 7c, f, g) are based on residual differences between the monthly aggregate groundwater mean and monthly means for the individual sites (normal distribution; standard deviation $=6.2 \mathrm{mg} \mathrm{L}^{-1}$ ). Parallel to groundwater recharge estimates, annual average NLRC values are presented (Table 5), but the three-year mean values provide estimates of average annual load that are less influenced by inter-annual storage. 

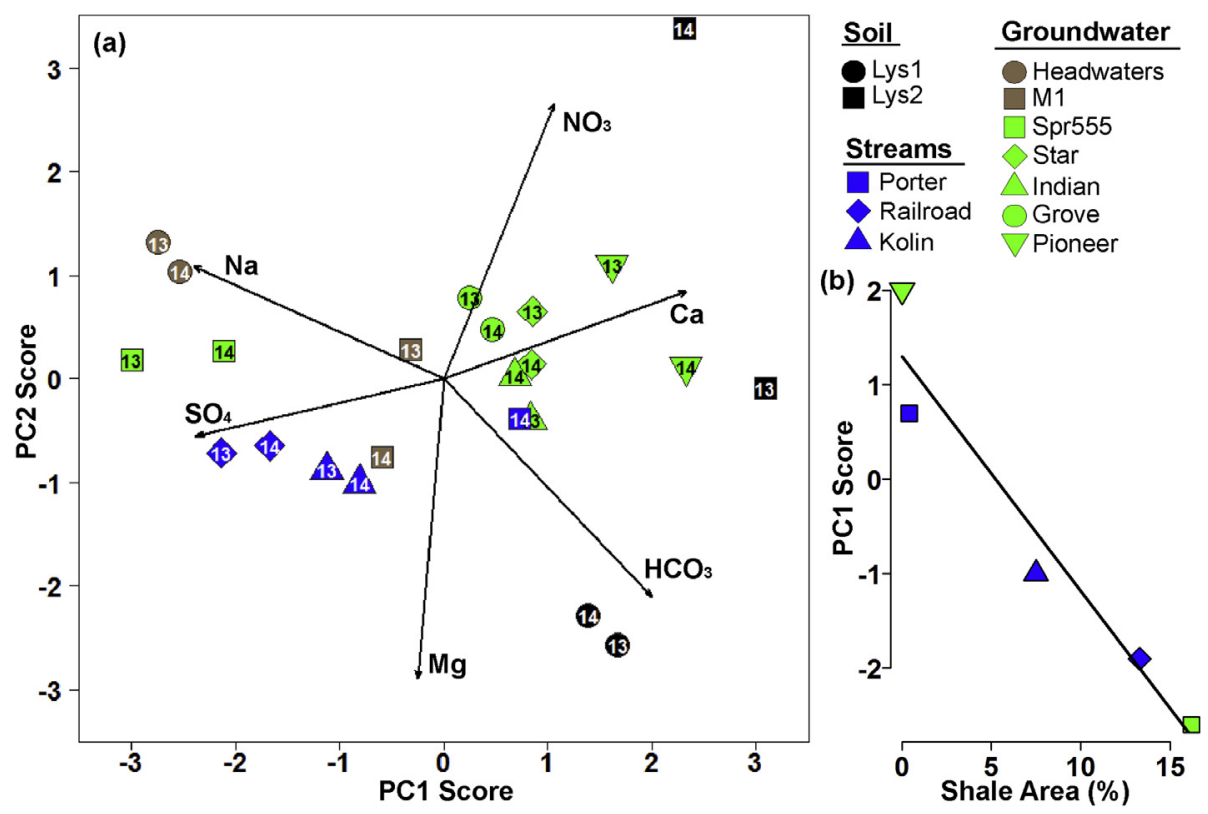

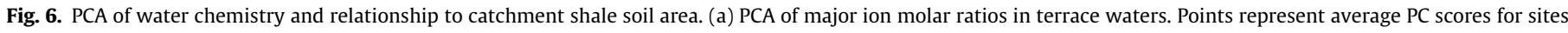

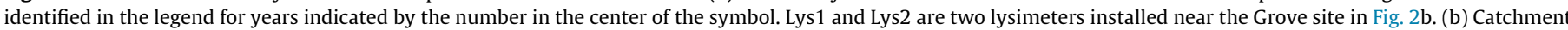

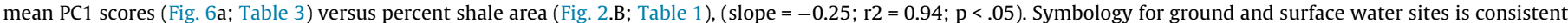
with that in Fig. 2.

Table 4

Principal component loadings for major ions.

\begin{tabular}{lll}
\hline Major Ion & PC1 & PC2 \\
\hline $\mathrm{Na}^{-}$ & $\mathbf{- 0 . 5 1}$ & 0.23 \\
$\mathrm{SO}^{2-}$ & $\mathbf{- 0 . 5 1}$ & -0.12 \\
$\mathrm{Ca}^{2+}$ & $\mathbf{0 . 5 0}$ & 0.18 \\
$\mathrm{HCO}_{3}^{-}$ & $\mathbf{0 . 4 3}$ & $-\mathbf{0 . 4 5}$ \\
$\mathrm{Mg}^{2+}$ & -0.05 & $\mathbf{0 . 6 2}$ \\
$\mathrm{NO}_{3}^{-}$ & 0.22 & $\mathbf{0 . 5 7}$ \\
\hline
\end{tabular}

The 2012-14 mean nitrate-N concentration for Porter Creek $\left(19.3 \pm 1.8 \mathrm{mg} \mathrm{L}^{-1}\right)$ was similar to that for aggregate groundwater $\left(20.4 \pm 6.4 \mathrm{mg} \mathrm{L}^{-1}\right)$, while three-year mean concentrations in Louse creek at both Railroad $\left(12.1 \pm 3.7 \mathrm{mg} \mathrm{L}^{-1}\right)$ and Kolin $(10.0 \pm 2.4 \mathrm{mg}$ $\mathrm{L}^{-1}$ ) were approximately half that in aggregate groundwater (Fig. 4, Table 2), a pattern also apparent in the time series data (Fig. 7c). Instantaneous nitrate-N loads were calculated for each visit to the Kolin and Porter sites (Fig. 7f-g) using measured concentration and measured Q. Values ranged from 31.3 to 373.8 with a mean of $109 \mathrm{~kg} \mathrm{~N} \mathrm{day}^{-1}$ for Kolin while values for Porter Creek ranged from 73.8 to 295.7 with a mean of $131 \mathrm{~kg} \mathrm{~N}$ day $^{-1}$. Normalizing these values to the cultivated area within the catchments produces a mean of $5.3 \pm 3.7 \mathrm{~kg} \mathrm{~N} \mathrm{ha}^{-1} \mathrm{yr}^{-1}$ for Kolin and a mean of $18.6 \pm 7.5 \mathrm{~kg} \mathrm{~N} \mathrm{ha}^{-1} \mathrm{yr}^{-1}$ for Porter (Fig. $7 \mathrm{f}-\mathrm{g}$ ). These values represent nitrate- $\mathrm{N}$ loads leaving the Moccasin terrace after potential losses in the stream-riparian system, and hence constitute a conservative lower bound on $\mathrm{N}$ yields from the landscape over time during the study.

Riparian nitrate loss was estimated for six site visit trips during the period from July to November 2013, when no storm related peaks in the stream hydrographs were present. Apparent riparian nitrate loss during this period averaged 53\% (range: 43-60) for Kolin and 16\% (range: 10-23) for Porter Creek (Supplemental Fig. 2). Apparent riparian losses normalized to cultivated area within the catchments during this period averaged $3.7 \mathrm{~kg} \mathrm{~N} \mathrm{ha}^{-1} \mathrm{yr}^{-1}$ (range: 3.0-4.3) for Kolin and $2.8 \mathrm{~kg} \mathrm{~N} \mathrm{ha}^{-1} \mathrm{yr}^{-1}$ (range: 1.8-4.8) Porter Creek, but were higher on average for Kolin (Supplemental Fig. 2).

\subsection{Groundwater residence time}

Groundwater residence time estimated by ${ }^{3} \mathrm{H}-{ }^{3} \mathrm{He}$ apparent age for the open M1 well bore was $1.7 \pm 0.5 \mathrm{yr}$ on 9 August 2012 (Miller, 2013) and was $5.2 \pm 0.57 \mathrm{yr}$ on 25 May 2014 (Table 6). Depth-specific sampling in M1 using packers on 24 May 2014 produced ages of $3.9 \pm 0.56 \mathrm{yr}$ for the bottom of the well $(5.2-5.7 \mathrm{~m})$ and $1.2 \pm 0.65 \mathrm{yr}$ for the top of the screening interval $(2.6-3.4 \mathrm{~m})$. Grove and Indian springs sampled for ${ }^{3} \mathrm{H}-{ }^{3} \mathrm{He}$ apparent ages on 24 May 2014 produced values of $0.8 \pm 0.5$ and $-0.8 \pm 0.9 \mathrm{yr}$ (effectively zero), respectively. The mean of ${ }^{3} \mathrm{H}^{3} \mathrm{He}$ apparent age values observed in 2014 in the open M1 well bore and the two springs was $1.8 \mathrm{yr}$ (st $\mathrm{dev}=3.1 \mathrm{yr}$ ). Estimated turnover times based on aquifer volume and discharge were approximately an order of magnitude longer at 23 and $20 \mathrm{yr}$ for Kolin and Porter catchments respectively (Table 7 ).

\section{Discussion}

Our results provide a landscape-scale perspective on the fate and transport of nitrate from soils to groundwater to stream networks in a non-irrigated agrosystem. We found that $\mathrm{N}$ loss to nitrate leaching represents up to one third of typical fertilizer $\mathrm{N}$ inputs over a three-year crop rotation, but that fallow within a crop rotation may allow for a disproportionate amount of nitrate leaching to groundwater. These results allow assessment of the differences between the two largest stream catchments draining the Moccasin terrace, which were evaluated with respect to leaching rate and riparian denitrification losses. This study highlights opportunities for targeting reductions in deleterious leaching losses and enhancement of beneficial $\mathrm{N}$ losses due to riparian denitrification.

\subsection{Connection of soil, ground and surface waters within Moccasin terrace}

Delineation of the process domains controlling nitrate dynamics in lower-relief sedimentary basins requires consideration of 


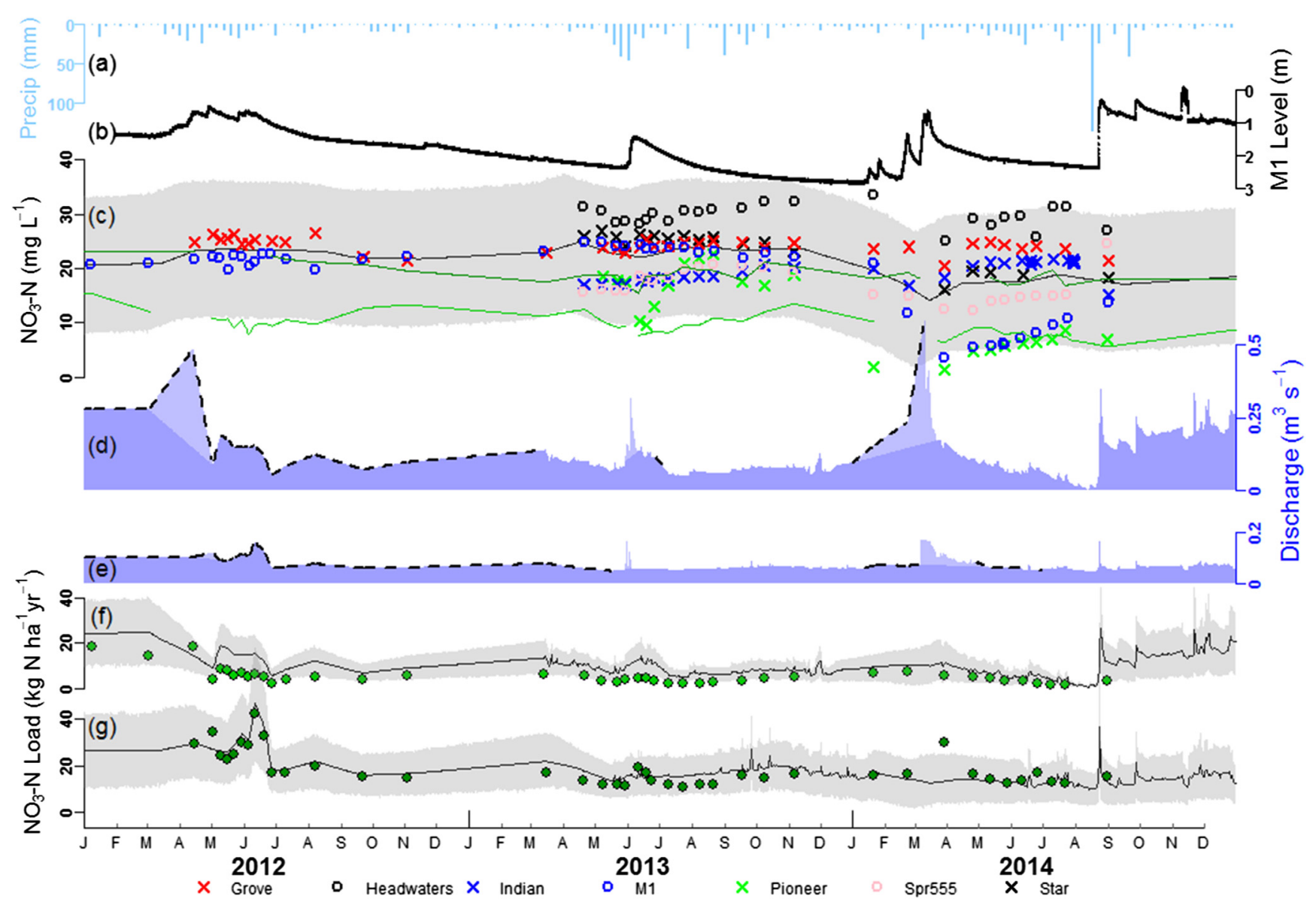

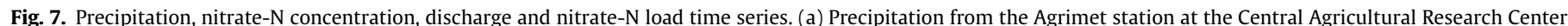

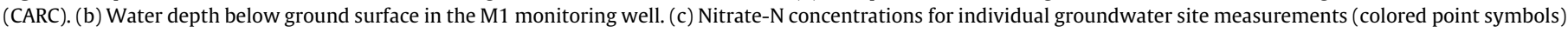

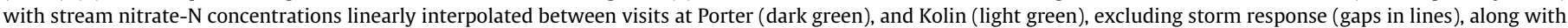

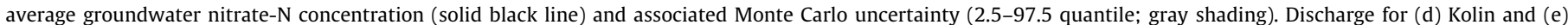

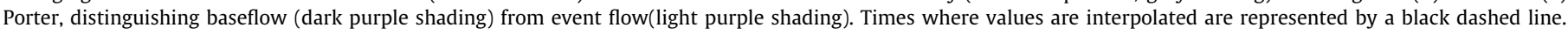

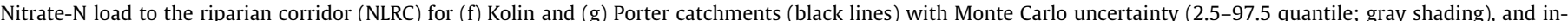

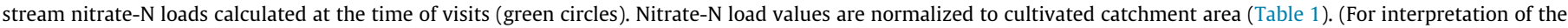
references to colour in this figure legend, the reader is referred to the web version of this article.)

Table 5

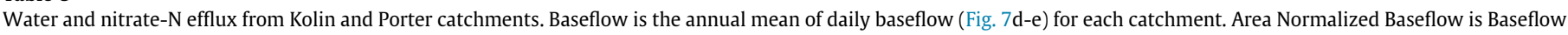

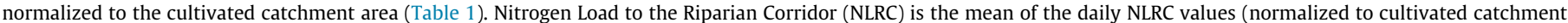
area) in Fig. 7F-G with 2.5 and 97.5 quartile values in parentheses.

\begin{tabular}{|c|c|c|c|c|}
\hline Stream & Year & $\begin{array}{l}\text { Baseflow } \\
\left(\mathrm{L} \mathrm{s}^{-1}\right)\end{array}$ & 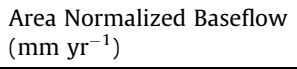 & $\begin{array}{l}\text { NLRC } \\
\left(\mathrm{kg} \mathrm{N} \mathrm{ha}^{-1} \mathrm{yr}^{-1}\right)\end{array}$ \\
\hline Kolin & $\begin{array}{l}2012 \\
2013 \\
2014 \\
3 \text { yr mean }\end{array}$ & $\begin{array}{l}150 \\
94 \\
136 \\
127\end{array}$ & $\begin{array}{l}63 \\
40 \\
57 \\
54\end{array}$ & $\begin{array}{l}14.1(13.6 ; 14.5) \\
9.2(8.9 ; 9.5) \\
10.1(9.7 ; 10.5) \\
11.1(10.9 ; 11.4)\end{array}$ \\
\hline Porter & $\begin{array}{l}2012 \\
2013 \\
2014 \\
3 \text { yr mean }\end{array}$ & $\begin{array}{l}84 \\
62 \\
64 \\
69\end{array}$ & $\begin{array}{l}104 \\
77 \\
79 \\
87\end{array}$ & $\begin{array}{l}23.4(22.7 ; 24.1) \\
17.9(17.4 ; 18.4) \\
14.0(13.5 ; 14.5) \\
18.4(18.1 ; 18.8)\end{array}$ \\
\hline
\end{tabular}

the relationship between stratigraphy and the land surface that characterizes the hydrogeologic and geomorphic context (Montgomery, 1999; Montgomery, 2004; Capell et al., 2011; Tesoriero et al., 2013), particularly in contrast with studies in mountain catchments where $\mathrm{N}$ transport to streams may be assumed to follow hydraulic gradients suggested by surface topography alone (e.g., Gardner and McGlynn, 2009). Within the Moccasin terrace process domain, the alignment between surface water chemistry and catchment soil chemistry (Fig. 6b), suggests accuracy in our approach to groundwater catchment delineation. In addition, the alignment of ground and surface water chemical composition with SSURGO map unit chemical composition for upgradient soils (Fig. 2b, Fig. 6a) provides support for our first hypothesis that ground and surface water chemical composition are primarily controlled by the aggregate character of terrace soils draining to a sampling location. 
Table 6

Groundwater apparent age based on tritium/helium analysis.

\begin{tabular}{llll}
\hline Site & $\begin{array}{l}\text { Sample } \\
\text { Date }\end{array}$ & Apparent Age (yr) & $\begin{array}{l}\text { Uncertainty } \\
(\mathrm{yr})\end{array}$ \\
\hline M1 (no packer) & $8 / 9 / 2012$ & 1.7 & 0.5 \\
M1 (no packer) & $5 / 25 / 2014$ & 5.22 & 0.57 \\
M1 top (2.6-3.1 m) & $5 / 24 / 2014$ & 1.23 & 0.65 \\
M1 bottom (5.2-5.7 m) & $5 / 24 / 2014$ & 3.91 & 0.56 \\
Indian Spring & $5 / 25 / 2014$ & -0.78 & 0.91 \\
Grove Spring & $5 / 25 / 2014$ & 0.84 & 0.5 \\
\hline
\end{tabular}

Table 7

Groundwater turnover time. Calculated as estimated aquifer volume $\left[\mathrm{L}^{3}\right]$ (assuming $50 \%$ of gravel thickness is saturated) divided by baseflow $\left[\mathrm{L}^{3} \mathrm{~T}^{-1}\right]$

\begin{tabular}{llll}
\hline Catchment & $\begin{array}{l}\text { Aquifer Volume } \\
\left(\mathrm{m}^{3}\right)\end{array}$ & $\begin{array}{l}\text { Mean Baseflow } \\
\left(\mathrm{m}^{3} \mathrm{y}^{-1}\right)\end{array}$ & $\begin{array}{l}\text { Turnover Time } \\
(\mathrm{y})\end{array}$ \\
\hline Porter & $5.0 \mathrm{E}+07$ & $2.21 \mathrm{E}+06$ & 23 \\
Kolin & $8.0 \mathrm{E}+07$ & $3.99 \mathrm{E}+06$ & 20 \\
\hline
\end{tabular}

\subsection{Nitrogen concentrations and soil-groundwater connections}

The mean groundwater nitrate- $\mathrm{N}$ concentration we observed for the Moccasin aquifer $\left(20.4 \mathrm{mg} \mathrm{L}^{-1}\right)$ is above the 75 th percentile for a Montana statewide agricultural well network (Schmidt, 2009), is near the 95th percentile of US concentrations reported by Puckett et al. (2011), and is approximately double the highest 2000-2004 median US well network concentrations reported by Rupert (2008). It is similar, however, to mean values reported for other shallow groundwater underlying dryland small grain production in Montana (20 $\mathrm{mg} \mathrm{L}^{-1}$; Nimick and Thamke, 1998) and Eastern Washington (19.3 $\mathrm{mg} \mathrm{L}^{-1}$; Kelley et al., 2013). The high concentrations are likely a function of the proximity of easily leachable soils to the shallow Moccasin aquifer, where limited volume and reduced denitrification potential result in vulnerability to nitrate pollution. Furthermore, this aquifer lacks inputs of low nitrate recharge water from mountain front stream recharge or from extensive irrigation, both of which can dilute groundwater nitrate in systems where they are present.

Consistent with global patterns of pronounced seasonality in groundwater recharge (Jasechko et al., 2014), the Moccasin aquifer receives most recharge in the pre-growing season months. This is evident from the rise in groundwater level with spring precipitation observed annually (Fig. 7), juxtaposed with a general lack of response to precipitation during the growing season. Flux to groundwater can be expected to be larger from soils with high water storage from the previous season (Nippgen et al., 2016) and soil moisture storage is purposefully created with fallow land use (Zeleke et al., 2014). Higher recharge from post-fallow fields, coupled with higher nitrate concentrations in post-fallow soil water (25.4 $\mathrm{mg} \mathrm{L}^{-1}$ ) than post-grain soil water $\left(11.6 \mathrm{mg} \mathrm{L}^{-1}\right)$, suggests that fallow rotations may result in disproportionately high leaching of $\mathrm{N}$ to groundwater.

While fallow land use makes up only $25 \%$ of the cultivated terrace surface (Table 1 ), its importance to $\mathrm{N}$ leaching is supported by nitrate- $\mathrm{N}$ concentrations in groundwater $\left(20.4 \mathrm{mg} \mathrm{L}^{-1}\right)$ that are more similar to post-fallow than post-grain soils (Fig. 4). Similarity between post-fallow lysimeter and groundwater nitrate concentrations provides support for our first hypothesis, that minimal denitrification occurs in groundwater. In future work, the range of lysimeter nitrate concentrations (Kelley, 2015; Mariotti et al., 2015) we observed could be coupled with daily deep percolation rates to provide more insight about crop rotation effects on leaching. In the simplest terms however, significantly lower soil nitrate concentrations observed post-grain versus post-fallow suggest that replacing fallow with continuous cropping - potentially in the form of water and $\mathrm{N}$ efficient cover crops or legumes - would be a step toward reducing groundwater nitrate- $\mathrm{N}$ concentrations below the drinking water standard of $10 \mathrm{mg} \mathrm{L}^{-1}$.

\subsection{Nitrate leaching rates}

Landform-average nitrate leaching rates presented here (11-18 $\mathrm{kg} \mathrm{N} \mathrm{ha}^{-1} \mathrm{yr}^{-1}$ ) for the Moccasin terrace are $19-31 \%$ of average standard fertilizer $\mathrm{N}$ application over a three-year rotation in the study area ( $\sim 90 \mathrm{~kg} \mathrm{~N} \mathrm{ha}^{-1} \mathrm{yr}^{-1}$ for each of two crop years and zero for fallow year) during the study (John et al., 2017). However, these values should not be interpreted as applied fertilizer lost directly to leaching. Mineralization of SON during fallow periods is an important component of leaching loss at this site that remains difficult to quantify (Custer, 1976; Miller, 2013; John et al., 2017). Our results agree with general findings by John et al. (2017), that leaching rates are higher post-fallow than post-crop (pea), but average leaching rates in that 2013-2014 field-scale study were notably higher $\left(\sim 50 \mathrm{~kg} \mathrm{~N} \mathrm{ha}^{-1} \mathrm{yr}^{-1}\right)$ than our leaching estimates. One possible explanation for the discrepancy is the set of conservative assumptions in our approach (Section 2.4 and Supplemental Material Section 4.3), including possible denitrification at a few groundwater sites during periods where measured dissolved oxygen was below $2 \mathrm{mg} \mathrm{L}^{-1}$ (Supplemental Fig. 3). Uncertainty in the field based approach is another possible explanation, along with the fact that our study integrates leaching losses over years to decades, while the field-scale study quantifies leaching for 2013 and 2014. The fact that our leaching values are lower than those of John et al. (2017), provides support for our suggestion that leaching estimates presented in this study are conservatively low. Notably, values presented here are comparable to rates $\left(13 \pm 7 \mathrm{~kg} \mathrm{~N} \mathrm{ha}^{-1} \mathrm{yr}^{-1}\right)$ from a study in eastern Washington that used a 12 ha tile drainage network to delineate a process domain within a small grain landscape where leaching was $12-15 \%$ of applied fertilizer rates (Kelley et al., 2017).

Area-normalized baseflow in the Kolin catchment is approximately one third lower than in Porter, a result that propagates into the estimated leaching rate differences between the two catchments (Table 5). This difference may reflect greater soil water storage capacity and/or less groundwater storage capacity within the Kolin catchment relative to Porter. The Kolin catchment has a larger fraction of area mapped as the thicker (Danvers series) calcareous soils (Fig. 2b, Table 1), while the Porter catchment has a higher fraction of the thinner (Judith series) calcareous soils. More potential for water storage in the thicker soils of the Kolin catchment could retain more infiltrated precipitation within the root zone, making it available for loss to evapotranspiration and reducing deep percolation/leaching. At the same time, the mean depth to shale and associated aquifer volume is less in the Kolin catchment than the Porter catchment (Table 1). In the higher elevations of the Kolin catchment, where shale is at or near the surface, soils may be subject to saturation excess overland flow, halting the recharge of groundwater from deep percolation/leaching. The Kolin catchment is likely to have a combination of both higher soil moisture storage capacity and less groundwater storage capacity, resulting in lower deep percolation and leaching rates relative to the Porter catchment. It is also possible that differences in riparian corridor evapotranspiration between the two catchments (i.e., more at Kolin) are contributing to lower area-normalized baseflow for Kolin.

\subsection{Riparian $N$ losses}

Our results suggest substantial losses of nitrate in the riparian corridor, as has been observed in previous studies (Lowrance et al., 1984; Hedin et al., 1998; Bohlke et al., 2002; Mulholland 
et al., 2009; Zarnetske et al., 2011), a finding that supports our second hypothesis. The estimated loss rate of $14 \%$ for Porter is similar to that predicted by Mulholland et al. (2008) for small streams $\left(>100 \mathrm{~L} \mathrm{~s}^{-1}\right)$, while the $53 \%$ estimate for Louse Creek above Kolin is far higher than predicted from other studies. Higher loss rates in Louse Creek corridor may be due to difference in the fraction of groundwater discharged through more diffuse seeps versus more focused springs. Groundwater discharging through seeps has prolonged contact with soil that can facilitate denitrification (Williams et al., 2015), while higher discharge rates through coarse substrate springs likely promotes less denitrification. Persistence of losses into November (Supplemental Fig. 2) beyond the peak season for in-stream primary productivity suggests that denitrification in this riparian system may play a larger role relative to plant uptake. This dominance of denitrification is atypical across biomes (Mulholland et al., 2008), but may be common in systems not limited by $\mathrm{N}$. These findings merit further exploration based on the isotopic composition of nitrate.

\subsection{Groundwater nitrate over time and expected timescale of response to changing inputs}

The rate of increase in nitrate- $\mathrm{N}$ concentrations in the M1 well from 1994 to $2014\left(0.67 \pm 0.09 \mathrm{mg} \mathrm{L}^{-1} \mathrm{yr}^{-1}\right)$ is two- to fivefold higher than the rates of increase reported in national studies (Dubrovsky et al., 2010; Puckett et al., 2011). Over the same period, water levels in groundwater have been variable but do not show a trend (Fig. 3), suggesting that recharge rates have not changed. Therefore, the most likely explanation for increases in groundwater nitrate concentrations is that leached nitrate concentrations in recharge have increased. Apparent groundwater ages of $1.8 \pm 3.1$ yr based on ${ }^{3} \mathrm{H}-{ }^{3} \mathrm{He}$ values are aligned with some of the youngest reported in other studies (<2yr from Williams et al., 2015) and suggest that groundwater nitrate concentration only lags a few years behind changes in leachate concentration. However, the fact that apparent groundwater age is ten-fold less than calculated turnover time based on aquifer volume (20-23 yr) suggests that a substantial proportion of the aquifer is bypassed by flows that mix more slowly with the total volume. Paleo-channels carved in the shale surface during terrace formation (Hancock and Anderson, 2002) or differentially sorted gravel channels within gravel deposits (Ritter, 1967; Stamm et al., 2013) may constitute important pathways of preferential flow through the terrace aquifer. Areas of lower hydrologic conductivity - outside preferential flow paths will turn over more slowly. Aquifer zones with longer turnover times will add to lag time in groundwater nitrate concentration response to changes in leachate concentration from management changes. Collection of ${ }^{3} \mathrm{H}-{ }^{3} \mathrm{He}$ time series data for springs and wells could help characterize differences in groundwater age distributions over seasons and different aquifer zones, which could help refine understanding of expected lag times in groundwater response to inputs.

County level data for Judith Basin County indicates that in the 1990s, the rate of $\mathrm{N}$ applied in fertilizer surpassed the rate of $\mathrm{N}$ removed in grain (Miller, 2013). The low spatial resolution of the county level data and the dynamic role of soil organic matter as a soil $\mathrm{N}$ storage reservoir preclude simple conclusions about nitrate concentration in leachate from the yield and fertilizer data. Nonetheless, the multi-decadal $\mathrm{N}$ data for yield and fertilizer input provides interesting context for interpreting the concentration trend in the M1 monitoring well and warrants further exploration.

\subsection{Value of participatory approach to hydrologic investigation}

For purposes of exploring hydrologic drivers of nitrate leaching in agricultural settings, the participatory approach of this work allowed us to benefit from local farmer knowledge of the landscape, provided access to sampling sites that otherwise would not have been possible, and facilitated development of effective strategies to communicate results to the agricultural community, thus potentially influencing changes in behavior to mitigate nitrate pollution in this area (Jackson-Smith et al., in review). Basins draining Montana rank below the 15th percentile of MARB basins for total $\mathrm{N}$ yield, but our study area includes nitrate concentrations ranking among the highest in national assessments (Goolsby et al., 1999; Dubrovsky et al., 2010; Puckett et al., 2011). Thus, while Montana's role in eutrophication of the Gulf of Mexico is small, groundwater nitrate pollution challenges are large from the perspective of communities within the state, and as reflected in an increasing number of regional studies globally (Bohlke and Denver, 1995; Flipo et al., 2007; Wong et al., 2015; Ameur et al., 2016; Niu et al., 2017). Work at the mesoscale landscape level to characterize and address groundwater contamination issues is important both from the perspective of isolating process domains within which a similar set of hydrologic and agronomic drivers are at play, but also for leveraging a scale at which management and environmental effects can be explicitly connected and effectively addressed by local communities (Wilbanks, 2015).

\section{Conclusions}

In conclusion, the Moccasin terrace exhibits close connections between soil water and groundwater, and between groundwater and streams. This setting provides a unique opportunity to directly observe landscape-scale movement of soil solutes as they travel through groundwater storage and are exported via stream discharge. Our results indicate nitrate leaching rates up to one third the rate of fertilizer $\mathrm{N}$ input over a standard three-year crop rotation, but losses may be more heavily weighted to the post-fallow period within the rotation, and mineralized SON is likely an important source of leached $\mathrm{N}$. The possible influence of the practice of fallowing on groundwater nitrate concentrations suggests that replacing grain-fallow rotations with continuous-crop rotations could reduce groundwater nitrate levels. Tracer-based apparent groundwater ages ranging up to five years suggest that groundwater nitrate concentrations could respond relatively quickly to changing nitrate concentrations in leachate; however, wholeaquifer turnover times on the order of decades suggest longer lag times are possible. Reduced groundwater nitrate concentrations should directly reduce $\mathrm{N}$ loads to surface water, especially in catchments with high baseflow index such as those in our study area. Additional surface water quality benefits may be achievable if drivers for the higher riparian $\mathrm{N}$ loss rates observed for Kolin versus Porter catchment can be further characterized and addressed with management.

Our research approach included individual profile-scale observations to infer soil processes within a field-scale management context, which we combined with ground and surface water observations to infer landscape-scale processes. This multi-scale approach allows inference about $\mathrm{N}$ processing that would not have been possible with observations only in soils, wells, or streams. Moreover, our participatory study design facilitated local farmer input and collaboration, resulting in improved access to and understanding of research sites. The demonstrated connection between soil, ground, and surface water in the study area became a working model in an open dialog that allowed agricultural producers to evaluate their role in landscape-scale water quality issues and to help identify management strategies that would be practical and effective. This type of multi-scale process based research, coupled with a participatory approach to developing shared understanding of both management choices and environmental consequences, 
could improve progress toward addressing environmental issues while sustaining farm viability across a variety of contexts (Committee on Twenty-First Century Systems Agriculture, 2010; Seitzinger et al., 2010).

\section{Acknowledgements}

The authors would like to thank the local project advisory committee, who represented county Extension, NRCS, MT Salinity Control, the Health District, county commissioners, agricultural business owners, and the MSU Central Agricultural Research Center (CARC). CARC superintendent Dave Wichman provided assistance in the form of local contacts, vehicle and equipment use, accommodations, and knowledge of the study area. The sixmember producer research advisory group (PRAG) conducted management trials on their farms and provided invaluable insights on data collected from a farm management perspective. Data collection and analysis conducted by Christine Miller from 2012-2013 for her master's thesis was foundational for framing of this work. Kyle Mehrens and Robby Robertson along with a number of MSU undergraduates helped with instrumentation and data collection. A special thank you to Simon Fordyce who was the lead field technician for the majority of the field campaign. This work was funded by the United States Department of Agriculture, National Institute of Food and Agriculture [grant number 2011-51130-31121, 2011]. Additional funding was provided by MSU Extension, the Montana Fertilizer Advisory Committee, the Montana Agricultural Experiment Station, and MSU Institute on Ecosystems.

\section{Appendix A. Supplementary data}

Supplementary data associated with this article can be found, in the online version, at https://doi.org/10.1016/j.jhydrol.2017.10. 018.

\section{References}

Ameur, M., Hamzaoui-Azaza, F., Gueddari, M., 2016. Nitrate contamination of Sminja aquifer groundwater in Zaghouan, northeast Tunisia: WQI and GIS assessments. Desalination Water Treat. 57, 23698-23708. https://doi.org/ 10.1080/19443994.2015.1137495.

Anderson, M.P., Woessner, W.W., 1992. Applied Groundwater Modeling; Simulation of Flow and Advective Transport. AcadPress, San Diego, CA, United States.

Bauder, J.W., Sinclair, K.N., Lund, R.E., 1993. Physiographic and land-use characteristics associated with nitrate-nitrogen in montana groundwater. J. Environ. Qual. 22, 255-262.

Bauder, J.W., Smith, M., 2011. Nutrients and Water Quality Nutrients and Water Quality A Region 8 Collaborative Workshop - Workshop Summary and Recommendations.

Beaudoin, N., Saad, J.K., Van Laethem, C., Machet, J.M., Maucorps, J., Mary, B., 2005. Nitrate leaching in intensive agriculture in Northern France: Effect of farming practices, soils and crop rotations. Agric. Ecosyst. Environ. 111, 292-310. https://doi.org/10.1016/j.agee.2005.06.006.

Bohlke, J., Denver, J., 1995. Combined use of groundwater dating, chemical, and isotopic analyses to resolve the history and fate of nitrate contamination in 2 agricultural watersheds, atlantic coastal-plain. Maryland. Water Resour. Res. 31, 2319-2339. https://doi.org/10.1029/95WR01584.

Bohlke, J.K., Wanty, R., Tuttle, M., Delin, G., Landon, M., 2002. Denitrification in the recharge area and discharge area of a transient agricultural nitrate plume in a glacial outwash sand aquifer. Minnesota. Water Resour. Res. 38, 1105. https:// doi.org/10.1029/2001WR000663.

Campbell, C.A., Selles, F., Zentner, R.P., De Jong, R., Lemke, R., Hamel, C., 2006. Nitrate leaching in the semiarid prairie: Effect of cropping frequency, crop type, and fertilizer after 37 years. Can. J. Soil Sci. 86, 701-710.

Capell, R., Tetzlaff, D., Malcolm, I.A., Hartley, A.J., Soulsby, C., 2011. Using hydrochemical tracers to conceptualise hydrological function in a larger scale catchment draining contrasting geologic provinces. J. Hydrol. 408, 164-177. https://doi.org/10.1016/j.jhydrol.2011.07.034.

Carling, G.T., Mayo, A.L., Tingey, D., Bruthans, J., 2012. Mechanisms, timing, and rates of arid region mountain front recharge. J. Hydrol. 428, 15-31. https://doi. org/10.1016/j.jhydrol.2011.12.043.

CEC, C. for E.C., 2006. Ecological Regions of North America: Level I-II.
Clarke, W.B., Jenkins, W.J., Top, Z., 1976. Determination of tritium by mass spectrometric measurement of 3He. Int. J. Appl. Radiat. Isot. 27, 515-522. https://doi.org/10.1016/0020-708X(76)90082-X.

Committee on Twenty-First Century Systems Agriculture, 2010. Toward Sustainable Agricultural Systems in the 21st Century. National Academies Press, Washington, D.C.

Cook, P.G., Solomon, D.K., 1997. Recent advances in dating young groundwater chlorofluorocarbons, 3H3He and 85Kr. J. Hydrol. 191, 245-265. https://doi.org/ 10.1016/S0022-1694(96)03051-X.

Covino, T.P., McGlynn, B.L., 2007. Stream gains and losses across a mountain-tovalley transition: Impacts on watershed hydrology and stream water chemistry. Water Resour. Res. 43. https://doi.org/10.1029/2006WR005544.

Custer, S.G., 1976. Nitrate in ground water; a search for sources near Rapelje. Montana. Northwest Geol., 25-33

Diaz, R.J., Rosenberg, R., 2008. Spreading Dead Zones and Consequences for Marine Ecosystems. Science 321, 926-929. https://doi.org/10.1126/science.1156401.

Dubrovsky, N.M., Burow, K.R., Clark, G.M., Gronberg, J.M., Hamilton, P.A., Hitt, K.J., Mueller, D.K., Munn, M.D., Nolan, B.T., Puckett, L.J., Rupert, M.G., Short, T.M., Spahr, N.E., Sprague, L.A., Wilber, W.G., 2010. The quality of our Nation's waters-Nutrients in the Nation's streams and groundwater, 1992-2004: U.S. Geological Survey Circular 1350.

Flipo, N., Jeannée, N., Poulin, M., Even, S., Ledoux, E., 2007. Assessment of nitrate pollution in the Grand Morin aquifers (France): Combined use of geostatistics and physically based modeling. Environ. Pollut. 146, 241-256. https://doi.org/ 10.1016/j.envpol.2006.03.056.

Gardner, K.K., McGlynn, B.L., 2009. Seasonality in spatial variability and influence of land use/land cover and watershed characteristics on stream water nitrate concentrations in a developing watershed in the Rocky Mountain West. Water Resour. Res. 45, W08411. https://doi.org/10.1029/2008WR007029.

Goolsby, D.A., Battaglin, W.A., 2001. Long-term changes in concentrations and flux of nitrogen in the Mississippi River Basin, USA. Hydrol. Process. 15, 1209-1226. https://doi.org/10.1002/hyp.210.

Goolsby, D.A., Battaglin, W.A., Lawrence, G.B., Artz, R.S., Aulenbach, B.T., Hooper, R. P., Keeney, D.R., Stensland, G.J., 1999. Flux and Sources of Nutrients in the Mississippi-Atchafalaya River Basin: Topic 3 Report for the Integrated Assessment on Hypoxia in the Gulf of Mexico.

Hancock, G.S., Anderson, R.S., 2002. Numerical modeling of fluvial strath-terrace formation in response to oscillating climate. Geol. Soc. Am. Bull. 114, $1131-$ 1142.

Hansen, J.R., Refsgaard, J.C., Hansen, S., Ernstsen, V., 2007. Problems with heterogeneity in physically based agricultural catchment models. J. Hydrol. 342, 1-16. https://doi.org/10.1016/j.jhydrol.2007.04.016.

Hedin, L.O., von Fischer, J.C., Ostrom, N.E., Kennedy, B.P., Brown, M.G., Robertson, G. P. 1998. Thermodynamic constraints on nitrogentransformations and other biogeochemicalprocesses at soil-stream interfaces. Ecology 79, 684-703.

Houlton, B.Z., Boyer, E., Finzi, A., Galloway, J., Leach, A., Liptzin, D., Melillo, J. Rosenstock, T.S., Sobota, D., Townsend, A.R., 2013. Intentional versus unintentional nitrogen use in the United States: trends, efficiency and implications. Biogeochemistry 114, 11-23. https://doi.org/10.1007/s10533012-9801-5.

Jackson-Smith, D., Ewing, S., Jones, C., Sigler, A., Armstrong, A., in review. The road less travelled: Assessing the impacts of in-depth farmer and stakeholder participation in nitrate pollution research. J. Soil Water Conserv.

Jasechko, S., Birks, S.J., Gleeson, T., Wada, Y., Fawcett, P.J., Sharp, Z.D., McDonnell, J.J., Welker, J.M., 2014. The pronounced seasonality of global groundwater recharge. Water Resour. Res. 50, 8845-8867. https://doi.org/10.1002/2014WR015809.

John, A.A., Jones, C.A., Ewing, S.A., Sigler, W.A., Bekkerman, A., Miller, P.R., 2017 Fallow replacement and alternative nitrogen management for reducing nitrate leaching in a semiarid region. Nutr. Cycl. Agroecosystems 1-18. https://doi.org/ 10.1007/s10705-017-9855-9.

Keeler, B.L., Polasky, S., 2014. Land-use change and costs to rural households: a case study in groundwater nitrate contamination. Environ. Res. Lett. 9, 074002. https://doi.org/10.1088/1748-9326/9/7/074002.

Kelley, C.J., Keller, C.K., Brooks, E.S., Smith, J.L., Huyck Orr, C., Evans, R.d., 2017 Water and nitrogen movement through a semiarid dryland agricultural catchment: Seasonal and decadal trends. Hydrol. Process. 31, 1889-1899. https://doi.org/10.1002/hyp.11152.

Kelley, C.J., 2015. Hydrologic Controls on Nitrogen Cycling and Nitrate Transport Through the Vadose Zone of a Subsurface Artificially-Drained Dryland Agroecosystem in the Palouse Basin of Eastern Washington (PhD Dissertation). Washington State University.

Kelley, C.J., Keller, C.K., Evans, R.D., Orr, C.H., Smith, J.L., Harlow, B.A., 2013. Nitratenitrogen and oxygen isotope ratios for identification of nitrate sources and dominant nitrogen cycle processes in a tile-drained dryland agricultural field Soil Biol. Biochem. 57, 731-738. https://doi.org/10.1016/j.soilbio.2012.10.017.

Kunstmann, H., Kastens, M., 2006. Determination of stochastic well head protection zones by direct propagation of uncertainties of particle tracks. J. Hydrol. 323 215-229. https://doi.org/10.1016/j.jhydrol.2005.09.003.

Lim, K.J., Engel, B.A., Tang, Z.X., Choi, J., Kim, K.S., Muthukrishnan, S., Tripathy, D. 2005. Automated Web Gis based hydrograph analysis tool. WHAT. J. Am. Water Resour. Assoc. 41, 1407-1416. https://doi.org/10.1111/j.1752-1688.2005. tb03808.x.

Long, J.A., Lawrence, R.L., Miller, P.R., Marshall, L.A., 2014. Changes in field-level cropping sequences: indicators of shifting agricultural practices. Agric. Ecosyst. Environ. 189, 11-20. https://doi.org/10.1016/j.agee.2014.03.015. 
Lowrance, R., Todd, R., Fail, J., Hendrickson, O., Leonard, R., Asmussen, L., 1984 Riparian forests as nutrient filters in agricultural watersheds. BioScience 34 374-377. https://doi.org/10.2307/1309729.

Lyne, V.D., Hollick, M., 1979. Stochastic Time-Variable Rainfall-Runoff Modeling. In: ResearchGate. Presented at the Aust. Natl. conf. Publ. pp. 89-93.

Mariotti, M., Masoni, A., Ercoli, L., Arduini, I., 2015. Nitrogen leaching and residual effect of barley/field bean intercropping. Plant Soil Environ. 61, 60-65. https:/| doi.org/10.17221/832/2014-PSE.

MBMG, 2016, Montana Bureau of Mines and Geology, Groundwater Information Center, accessed March 2016, http://mbmggwic.mtech.edu/

Miller, C., 2013. Groundwater Nitrate Transport and Residence Time In A Vulnerable Aquifer Under Dryland Cereal Production (MS Thesis). Montana State University.

Montgomery, D.R., 2004. Observations on the role of lithology in strath terrace formation and bedrock channel width. Am. J. Sci. 304, 454-476. https://doi.org/ 10.2475/ajs.304.5.454.

Montgomery, D.R., 1999. Process domains and the river continuum. J. Am. Water Resour. Assoc. 35, 397-410. https://doi.org/10.1111/j.1752-1688.1999.tb03598.

Mulholland, P.J., Hall, R.O., Sobota, D.J., Dodds, W.K., Findlay, S.E.G., Grimm, N.B. Hamilton, S.K., McDowell, W.H., O’Brien, J.M., Tank, J.L., Ashkenas, L.R., Cooper L.W., Dahm, C.N., Gregory, S.V., Johnson, S.L., Meyer, J.L., Peterson, B.J., Poole, G. C., Valett, H.M., Webster, J.R., Arango, C.P., Beaulieu, J.J., Bernot, M.J., Burgin, A.J., Crenshaw, C.L., Helton, A.M., Johnson, L.T., Niederlehner, B.R., Potter, J.D., Sheibley, R.W., Thomas, S.M., 2009. Nitrate removal in stream ecosystems measured by $\mathrm{N}-15$ addition experiments: denitrification. Limnol. Oceanogr. 54 666-680. https://doi.org/10.4319/1o.2009.54.3.0666.

Mulholland, P.J., Helton, A.M., Poole, G.C., Hall, R.O., Hamilton, S.K., Peterson, B.J. Tank, J.L., Ashkenas, L.R., Cooper, L.W., Dahm, C.N., Dodds, W.K., Findlay, S.E.G., Gregory, S.V., Grimm, N.B., Johnson, S.L., McDowell, W.H., Meyer, J.L., Valett, H. M., Webster, J.R., Arango, C.P., Beaulieu, J.J., Bernot, M.J., Burgin, A.J., Crenshaw, C.L., Johnson, L.T., Niederlehner, B.R., O’Brien, J.M., Potter, J.D., Sheibley, R.W. Sobota, D.J., Thomas, S.M., 2008. Stream denitrification across biomes and its response to anthropogenic nitrate loading. Nature 452, 202-205. https://doi. org/10.1038/nature06686.

Nimick, D.A., Thamke, J.N., 1998. Extent, magnitude, and sources of nitrate in the Flaxville and underlying aquifers, Fort Peck Indian Reservation, northeastern Montana (No. WRI-98-4079). United States Geological Survey.

Nippgen, F., McGlynn, B.L., Emanuel, R.E., Vose, J.M., 2016. Watershed memory at the Coweeta Hydrologic Laboratory: the effect of past precipitation and storage on hydrologic response. Water Resour. Res. 52, 1673-1695. https://doi.org/ 10.1002/2015WR018196.

Niu, B., Wang, H., Loaiciga, H.A., Hong, S., Shao, W., 2017. Temporal variations of groundwater quality in the Western Jianghan Plain. China. Sci. Total Environ. 578, 542-550. https://doi.org/10.1016/j.scitotenv.2016.10.225.

NRCS OSD, Soil Survey Staff, Natural Resources Conservation Service, United States Department of Agriculture. Official Soil Series Descriptions. Available online. Accessed March 2015

Padbury, G., Waltman, S., Caprio, J., Coen, G., McGinn, S., Mortensen, D., Nielsen, G. Sinclair, R., 2002. Agroecosystems and land resources of the northern Great Plains. Agron. J. 94, 251-261.

Pizzol, L., Zabeo, A., Critto, A., Giubilato, E., Marcomini, A., 2015. Risk-based prioritization methodology for the classification of groundwater pollution sources. Sci. Total Environ. 506, 505-517. https://doi.org/10.1016/j. scitotenv.2014.11.014

Puckett, L.J., Tesoriero, A.J., Dubrovsky, N.M., 2011. Nitrogen Contamination of Surficial Aquifers-A Growing Legacy $\dagger$. Environ. Sci. Technol. 45, 839-844. https://doi.org/10.1021/es1038358.

Ritter, D.F., 1967. Terrace Development along the Front of the Beartooth Mountains, Southern Montana. Geol. Soc. Am. Bull. 78, 467-484. https://doi.org/10.1130/ 0016-7606(1967) 78[467:TDATFO]2.0.CO;2.

Rupert, M.G., 2008. Decadal-Scale Changes of Nitrate in Ground Water of the United States, 1988-2004. J. Environ. Qual. 37, S-240. doi:10.2134/jeq2007.0055

Sanford, W.E., Shropshire, R.G., Solomon, D.K., 1996. Dissolved gas tracers in groundwater: Simplified injection, sampling, and analysis. Water Resour. Res. 32, 1635-1642. https://doi.org/10.1029/96WR00599.
Scanlon, B.R., Reedy, R.C., Stonestrom, D.A., Prudic, D.E., Dennehy, K.F., 2005. Impact of land use and land cover change on groundwater recharge and quality in the southwestern US. Glob. Change Biol. 11, 1577-1593. https://doi.org/10.1111/ j.1365-2486.2005.01026.x.

Schmidt, C., Mulder, R., 2010. Groundwater and Surface Water Monitoring for Pesticides and Nitrate in the Judith River Basin, Central Montana. Montana Department of Agriculture. http://agr.mt.gov/Groundwater. Accessed 19 June 2017.

Schmidt, C.G., 2009. Permanent Monitoring Well Network Nitrate-N Summary Report 2003-2008. Montana Department of Agriculture, Agriculture Sciences Division, Groundwater Protection Program.

Seitzinger, S.P., Mayorga, E., Bouwman, A.F., Kroeze, C., Beusen, A.H.W., Billen, G., Van Drecht, G., Dumont, E., Fekete, B.M., Garnier, J., Harrison, J.A., 2010. Global river nutrient export: a scenario analysis of past and future trends. Glob. Biogeochem. Cycles 24, GB0A08. https://doi.org/10.1029/2009GB003587.

Smith, V.H., 2003. Eutrophication of freshwater and coastal marine ecosystems - A global problem. Environ. Sci. Pollut. Res. 10, 126-139. https://doi.org/10.1065/ espr2002.12.142.

Spalding, R.F., Exner, M.E., 1993. Occurrence of Nitrate in Groundwater-A Review. J. Environ. Qual. 22, 392-402. https://doi.org/ 10.2134/jeq1993.00472425002200030002x.

Stamm, J.F., Hendricks, R.R., Sawyer, J.F., Mahan, S.A., Zaprowski, B.J., Geibel, N.M., Azzolini, D.C., 2013. Late Quaternary stream piracy and strath terrace formation along the Belle Fourche and lower Cheyenne Rivers, South Dakota and Wyoming. Geomorphology 197, 10-20. https://doi.org/10.1016/ j.geomorph.2013.03.028

Tesoriero, A.J., Duff, J.H., Saad, D.A., Spahr, N.E., Wolock, D.M., 2013. Vulnerability of streams to legacy nitrate sources. Environ. Sci. Technol. 47, 3623-3629. https:// doi.org/10.1021/es305026x.

USDA, 2014. National Agricultural Statistics Service Cropland Data Layer (Online) http://nassgeodata.gmu.edu/CropScape/. Accessed 8 Sept 2016.

USDA SSURGO, Soil Survey Staff, Natural Resources Conservation Service, United States Department of Agriculture. Soil Survey Geographic (SSURGO) Database. Available online at https://sdmdataaccess.sc.egov.usda.gov. Accessed March 2012 .

USGS, 2012, U.S. Geological Survey, The National Map, 3DEP products and services: The National Map, 3D Elevation Program Web page, accessed September 2012. http://nationalmap.gov/3dep_prodserv.html.

Vitousek, P., 1994. Beyond global warming - Ecology and global change. Ecology 75, 1861-1876. https://doi.org/10.2307/1941591.

Vuke, S.M., Berg, R.B., Brien, H.E.O., 2002. Geologic Map of the Belt 30' x 60' Quadrangle, Central Montana.

Ward, M.H., deKok, T.M., Levallois, P., Brender, J., Gulis, G., Nolan, B.T., VanDerslice, J. International Society for Environmental Epidemiology, 2005. Workgroup report: Drinking-water nitrate and health-recent findings and research needs. Environ. Health Perspect. 113, 1607-1614.

Weissmann, G.S., Carle, S.F., Fogg, G.E., 1999. Three-dimensional hydrofacies modeling based on soil surveys and transition probability geostatistics. Water Resour. Res. 35, 1761-1770. https://doi.org/10.1029/1999WR900048.

Wilbanks, T.J., 2015. Putting "Place" in a multiscale context: Perspectives from the sustainability sciences. Environ. Sci. Policy 53, 70-79. https://doi.org/10.1016/j. envsci.2015.04.009.

Williams, M.R., Buda, A.R., Elliott, H.A., Collick, A.S., Dell, C., Kleinman, P.J.A., 2015. Linking nitrogen management, seep chemistry, and stream water quality in two agricultural headwater watersheds. J. Environ. Qual. 44, 910-920. https://doi. org/10.2134/jeq2014.10.0412.

Wong, W.W., Grace, M.R., Cartwright, I., Cook, P.L.M., 2015. Unravelling the origin and fate of nitrate in an agricultural-urban coastal aquifer. Biogeochemistry 122, 343-360. https://doi.org/10.1007/s10533-014-0045-4.

WRCC Gage \# 245761; Western Region Climate Center; Moccasin Experiment Station Weather Station gage; http://www.wrcc.dri.edu/cgi-bin/cliMAIN.pl? mt5761

Zeleke, K., Anwar, M., Liu, D., 2014. Managing crop stubble during fallow period for soil water conservation: field experiment and modelling. Environ. Earth Sci. 72, 3317-3327. https://doi.org/10.1007/s12665-014-3235-4. 